The University of Maine

DigitalCommons@UMaine

Marine Sciences Faculty Scholarship

School of Marine Sciences

3-14-2008

\title{
Satellite-Derived Variability in Chlorophyll, Wind Stress, Sea Surface Height, and Temperature in the Northern California Current System
}

\author{
R. M. Venegas \\ P. T. Strub \\ E. Beier \\ R. Letelier \\ Andrew Thomas \\ University of Maine - Main, thomas@maine.edu \\ See next page for additional authors
}

Follow this and additional works at: https://digitalcommons.library.umaine.edu/sms_facpub

\section{Repository Citation}

Venegas, R. M.; Strub, P. T.; Beier, E.; Letelier, R.; Thomas, Andrew; Cowles, T.; James, C.; Soto-Mardones, L.; and Cabrera, C., "Satellite-Derived Variability in Chlorophyll, Wind Stress, Sea Surface Height, and Temperature in the Northern California Current System" (2008). Marine Sciences Faculty Scholarship. 110.

https://digitalcommons.library.umaine.edu/sms_facpub/110

This Article is brought to you for free and open access by DigitalCommons@UMaine. It has been accepted for inclusion in Marine Sciences Faculty Scholarship by an authorized administrator of DigitalCommons@UMaine. For more information, please contact

um.library.technical.services@maine.edu. 
Authors

R. M. Venegas, P. T. Strub, E. Beier, R. Letelier, Andrew Thomas, T. Cowles, C. James, L. Soto-Mardones, and C. Cabrera 


\title{
Satellite-derived variability in chlorophyll, wind stress, sea surface height, and temperature in the northern California Current System
}

\author{
Roberto M. Venegas, ${ }^{1}$ P. Ted Strub, ${ }^{1}$ Emilio Beier, ${ }^{2}$ Ricardo Letelier, ${ }^{1,3}$ \\ Andrew C. Thomas, ${ }^{4}$ Timothy Cowles, ${ }^{1}$ Corinne James, ${ }^{1}$ Luis Soto-Mardones, ${ }^{5}$ \\ and Carlos Cabrera ${ }^{2}$ \\ Received 3 August 2007; accepted 23 November 2007; published 14 March 2008.
}

[1] Satellite-derived data provide the temporal means and seasonal and nonseasonal variability of four physical and biological parameters off Oregon and Washington $\left(41^{\circ}-48.5^{\circ} \mathrm{N}\right)$. Eight years of data $(1998-2005)$ are available for surface chlorophyll concentrations, sea surface temperature (SST), and sea surface height, while six years of data (2000-2005) are available for surface wind stress. Strong cross-shelf and alongshore variability is apparent in the temporal mean and seasonal climatology of all four variables. Two latitudinal regions are identified and separated at $44^{\circ}-46^{\circ} \mathrm{N}$, where the coastal ocean experiences a change in the direction of the mean alongshore wind stress, is influenced by topographic features, and has differing exposure to the Columbia River Plume. All these factors may play a part in defining the distinct regimes in the northern and southern regions. Nonseasonal signals account for $\sim 60-75 \%$ of the dynamical variables. An empirical orthogonal function analysis shows stronger intra-annual variability for alongshore wind, coastal SST, and surface chlorophyll, with stronger interannual variability for surface height. Interannual variability can be caused by distant forcing from equatorial and basin-scale changes in circulation, or by more localized changes in regional winds, all of which can be found in the time series. Correlations are mostly as expected for upwelling systems on intra-annual timescales. Correlations of the interannual timescales are complicated by residual quasi-annual signals created by changes in the timing and strength of the seasonal cycles. Examination of the interannual time series, however, provides a convincing picture of the covariability of chlorophyll, surface temperature, and surface height, with some evidence of regional wind forcing.

Citation: Venegas, R. M., P. T. Strub, E. Beier, R. Letelier, A. C. Thomas, T. Cowles, C. James, L. Soto-Mardones, and C. Cabrera (2008), Satellite-derived variability in chlorophyll, wind stress, sea surface height, and temperature in the northern California Current System, J. Geophys. Res., 113, C03015, doi:10.1029/2007JC004481.

\section{Introduction}

[2] Upwelling systems in Eastern Boundary Currents account for less than $1 \%$ of global ocean surface area but are recognized as some of the most productive marine ecosystems on the planet [Pauly and Christensen, 1995; Thomas et al., 2001]. Ocean-atmosphere interactions, characterized by latitudinal changes in seasonal wind forcing, solar radiation, periodicity of wind events and nonlocal forcing of the regional circulation, play a principal role in

\footnotetext{
${ }^{1}$ College of Oceanic and Atmospheric Sciences, Oregon State University, Corvallis, Oregon, USA.

${ }^{2}$ Centro de Investigación Científica y Educación Superior de Ensenada, Ensenada, Baja California, Mexico.

${ }^{3}$ Also at Centro de Estudios Avanzados en Ecología y Biodiversidad, Universidad Católica de Chile, Santiago, Chile.

${ }^{4}$ School of Marine Sciences, University of Maine, Orono, Maine, USA.

${ }^{5}$ Departamento de Física, Facultad de Ciencias, Universidad del BioBio, Concepcion, Chile.
}

Copyright 2008 by the American Geophysical Union. 0148-0227/08/2007JC004481 enhancing primary productivity within these regions. In the northeast Pacific, off the west coast of the United States, coastal features such as capes, bays and bottom topography also play a key role in the development of mesoscale circulation (i.e., eddies, meanders and colder, richer filaments) in this region [Ikeda and Emery, 1984; Strub et al., 1991a, 1991b; Kosro et al., 1991; Huyer et al., 1991; Hill et al., 1998]. For example, shallow banks, such as Heceta Bank (about $55 \mathrm{~km}$ offshore of Oregon at $44^{\circ} \mathrm{N}, 125^{\circ} \mathrm{W}$ ), provide a topographic disruption to cross and along shelf biophysical patterns [Castelao et al., 2005]. In addition, large riverine inputs, such as the Columbia River, can modify the hydrographic patterns along the coast. Confined to the surface Ekman layer, the Columbia River plume is advected offshore and southward during summer, and northward during winter along the Washington coast [Hickey, 1989; Thomas and Weatherbee, 2006].

[3] The California Current System (CCS) traverses this complex region, displaying variability in physical and biological properties on timescales ranging from subseasonal [Legaard and Thomas, 2008] and seasonal [Huyer et al., 


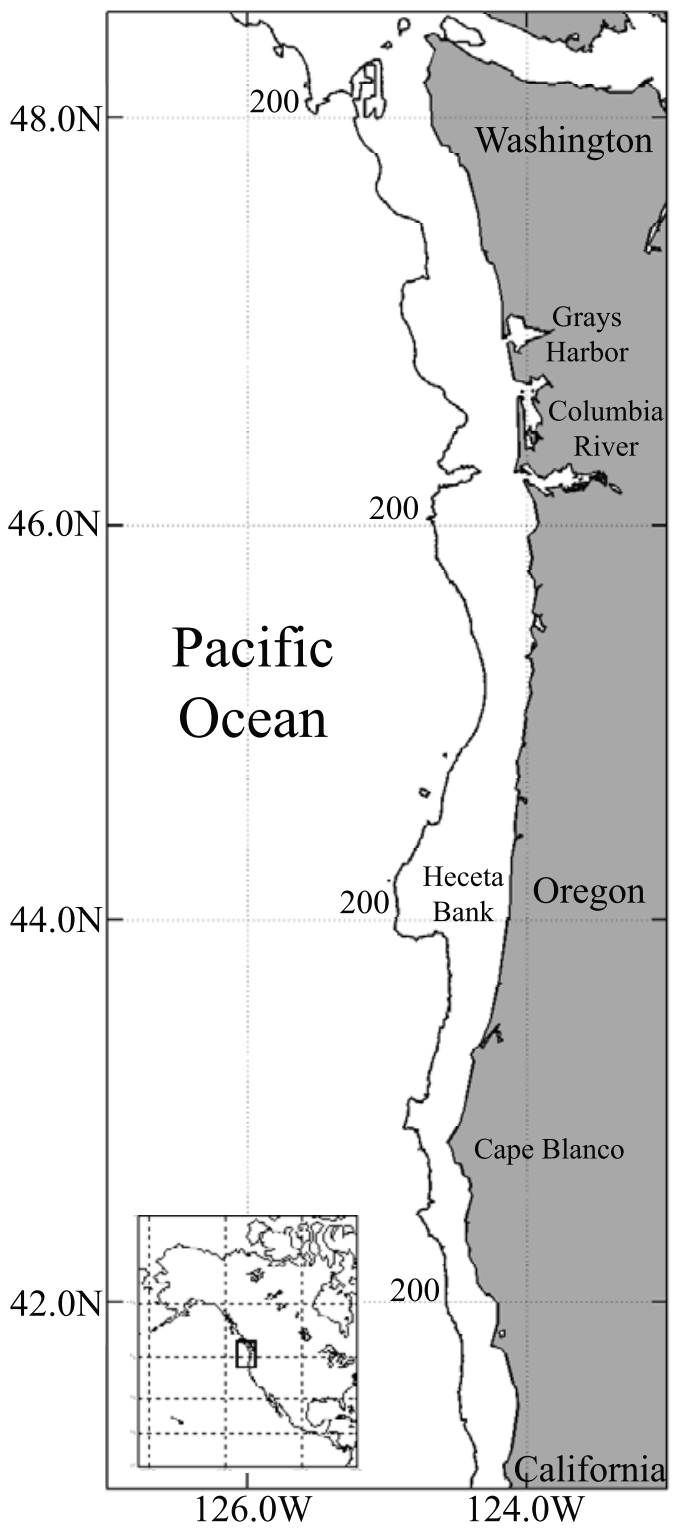

Figure 1. Map of study region along the northern California Current System. The 200-m isobath is shown to denote the outer boundary of the shelf.

1975, 1979; Strub et al., 1987a, 1987b; Lynn and Simpson, 1987; Hickey, 1989, 1998; Strub and James, 2000; Legaard and Thomas, 2006], to interannual [e.g., Chelton, 1982; Huyer and Smith, 1985; Strub and James, 2002; Huyer, 2003; Legaard and Thomas, 2006], to decadal [McGowan et al., 1996, 1998; Mantua et al., 1997; Chavez et al., 2003]. Within the northern CCS, the Washington and northern Oregon coasts are relatively straight with a narrow continental shelf, while the central and southern Oregon shelf has more topographic variation and a major cape (Cape Blanco). These spatial differences suggest that physical, chemical and biological patterns might display similar spatial differences.

[4] In addition, temporal variability in distant forcing, such as El Niño and La Niña conditions, often produce strong anomalies within the CCS domain [Smith et al., 2001; Chavez et al., 2002; Thomas et al., 2003]. This interaction between local and distant forcing creates temporal and spatial variability in both physical and biological variables that complicates the interpretation of relatively sparse, in situ data.

[5] The hydrographic conditions within the northern CCS (Figure 1) have been previously described [e.g., Huyer, 1983; Hickey, 1979, 1989, 1998; Smith et al., 1988, 2001; Mackas, 2006; Mackas et al., 2006] and the broad pattern of satellite-derived ocean color variability has been documented by several studies, principally examining seasonal patterns in phytoplankton surface chlorophyll concentration (CHL), and identifying specific bloom events and fronts [Strub et al., 1990; Thomas and Strub, 1989, 1990, 2001; Thomas et al., 2003]. Satellite-derived variability in sea surface height (SSH) has been used to describe seasonal and nonseasonal circulation patterns [Strub and James, 1995, 2000, 2002; Kelly et al., 1998] (see also P. T. Strub and C. James, Satellite comparisons of Eastern Boundary Currents: Resolution of circulation features in "coastal" oceans, in Monitoring the Oceans in the 2000s: An Integrated Approach, preprint, NASA-CNES, Biarritz, France). The seasonal distribution of fronts has also been described from sea surface temperature (SST) and CHL [Strub et al., 1990; Castelao et al., 2005]. Aircraft-derived wind stress (TAU) fields have been examined in several areas of the CCS [Enriquez and Friehe, 1995; Munchow, 2000], but scatterometer fields have yet to be systematically examined for this region of the CCS.

[6] Abbott and Zion [1985] and Pelaez and McGowan [1986] found that satellite-derived surface pigment patterns, corresponded well with coincident satellite-derived SST fields in both time and space. Abbott and Barksdale [1991] described the coupling of wind forcing and seasonal patterns of coastal pigment distribution, showing that wind forcing, particularly wind stress curl, plays an important role in their distribution [see Strub et al., 1990]. They also noted that changes in coastal topography can be an important factor in phytoplankton pigment distribution.

[7] These earlier studies set the stage for a more detailed examination of regional and local patterns of physical forcing and chlorophyll distribution. Here, we examine satellite ocean color data to improve our understanding of regional CHL variability along the northern CCS in relation to SST, SSH and TAU. Using the synoptic and repetitive coverage afforded by satellite data, we seek to provide a detailed description and quantification of variability across local to regional spatial scales, resolving intra-annual, annual and interannual variability of CHL, SST, SSH and TAU. We focus our analyses on the region from northern California to Juan de Fuca Straight, using high-resolution satellite-derived fields. This study complements the largerscale analyses of coarser satellite fields covering the entire California Current by Legaard and Thomas [2006, 2008].

\section{Data and Methods}

[8] The study region is shown in Figure 1, along with the 200-m isobath (the approximate outer edge of the continental shelf) and the identification of geographic features referred to in the text. Over this region, we evaluate eight years (January 1998 to December 2005) of satellite-derived surface CHL, SSH and SST data, and six years (January 
2000 to December 2005) of TAU data. We examine their temporal means and seasonal cycles, then remove the seasonal cycles to analyze at the nonseasonal variability. The nonseasonal variability is, in turn, divided into decadal, interannual and intra-annual timescales.

[9] Chlorophyll concentrations come from the Sea Viewing Wide Field of View Sensor (SeaWiFS), using the OC4 version 3 algorithm with standard NASA global coefficients [O'Reilly et al., 1998] at $1.2 \mathrm{~km}$ resolution. Daily fields are composited to form 8-day fields. SST data come from the Advanced Very High-Resolution Radiometer (AVHRR) on the NOAA-14 to NOAA-18 satellites. SST composites at $1.1 \mathrm{~km}$ resolution were constructed by selecting the clearest (less than 50\% cloud coverage) several images in each 8-day period, then using the warmest value at each pixel. This does not eliminate all clouds but reduces their influence and avoids the large loss of data caused by presently available (very conservative) cloud masks. Sea surface wind stress data come from daily QuikSCAT data in the Jet Propulsion Laboratory (JPL) archive. Averages are formed from daily fields over the same 8-day periods used for SST and CHL, with quarter-degree resolution.

[10] The along-track altimeter SSH data are also obtained from the JPL archive and include data from TOPEX and Jason-1 (both with a 10-day exact repeat period), Geosat Follow On (GFO) (with a 17.5-day exact repeat period), and ERS (with a 35-day exact repeat period) altimeters. These were initially processed using standard atmospheric corrections to produce along-track sea level anomalies. During this processing, the temporal means are removed from each along-track point to eliminate the unknown marine geoid. Gridded SSH fields are produced from the along-track SSH anomalies for 16-day periods using all available altimeters. Each period contains approximately one-and-a-half TOPEX/Jason exact repeat cycles, approximately one GFO cycle and one-half ERS cycle. Since the ERS ground tracks have a 17.5-day subcycle, they fill in a GFO-like pattern in each 16-day period. Before combining data from different altimeters into 2-D fields, the spatial mean over the study area for each altimeter is removed to reduce residual orbit errors. To replace the long-term temporal mean SSH, a climatological sea surface dynamic height field (SSDH) relative to 500 $\mathrm{m}$ was formed from the long-term means of temperature and salinity [Levitus et al., 1998] and added to each along-track $\mathrm{SSH}$ anomaly. Two-dimensional gridded SSH fields are produced using the method of successive correction [Strub and James, 2000] to combine all data from each 16-day period. As a side effect of the processing, removal of the spatial mean for each altimeter in each 16-day period also removes much of the dominant domain-wide annual rise and fall of SSH, caused by the large-scale seasonal steric height changes due to seasonal heating and cooling. This process does not remove the gradients that correspond to the spatial and temporal changes in geostrophic currents.

[11] The long-term (8-year and 6-year) temporal means of CHL, SST and TAU were formed from the 8-day composites. The climatological SSDH field serves as a very coarse substitute for the temporal mean for SSH field. The 8-day SST, CHL and TAU fields were then averaged to form individual 16-day fields, coincident with the 16-day SSH fields. These 16-day fields were averaged to form climatological monthly and bimonthly seasonal cycles.
[12] To form nonseasonal time series, harmonic seasonal cycles were first calculated by fitting annual and semiannual harmonics to each parameter at each grid point, using the 16-day time series:

$$
S_{(t)}=S_{0}+S_{a} * \cos \left(\omega t-\varphi_{1}\right)+S_{s} * \cos \left(2 \omega t-\varphi_{2}\right)+\operatorname{res}\left(S_{(t)}\right),
$$

where $S_{(t)}$ is time series; $S_{0}$ is long-term mean; $S_{a}$ is annual amplitude; $S_{S}$ is semiannual amplitude; res is residuals; $\omega$ is annual radian frequency $(2 \pi / 365.25$ days $) ; t$ is time; and $\varphi_{1}$ and $\varphi_{2}$ are phase of annual and semiannual harmonics. These seasonal cycles were subtracted from the 16-day time series to form nonseasonal fields. Note that this procedure removes only the stationary component of the seasonality. For this reason, changes in phase and strength of seasonal cycles during the record will contribute to nonseasonal anomalies [Legaard and Thomas, 2008]. Coherent nonseasonal variability within these large data sets was simplified using empirical orthogonal function (EOF) analyses based on singular value decomposition [Preisendorfer, 1988; Emery and Thomson, 1998]. For the vector wind stress, we used a joint EOF analysis of the $u$ and $v$ wind stress components simultaneously.

[13] We quantified variance in each of a series of timescale bands for each variable over the entire region. Using the 16-day time series, temporal variances of each variable at each grid point are calculated from the original time series, then they are spatially averaged over the study region. The stationary (harmonic) seasonal cycles are then removed at each grid point and the variances are recalculated. This quantifies the percent of total variance represented by the stationary seasonal cycles and nonseasonal signals. The first two EOF modes of the nonseasonal time series are then calculated (the nonseasonal EOF's described above). Considering these to represent $100 \%$ of the spatially coherent nonseasonal "signal," a quadratic fit and 11-point (176-day) running mean are then sequentially removed from each EOF time series, recalculating the variance after removing each signal. We refer to the long-period (quadratic fit) variability as the "decadal" variability, recognizing that the records are not long enough to characterize the real periodicity on over these timescales. The 11-point running mean is considered to represent "interannual" variability and the residual is called the "intra-annual" variability. Since the span of this filter is approximately $1 / 2$ year, the half-power period is $\sim 1$ year. Thus the intra-annual time series include periods of approximately one month (owing to the 16-day time step) to one year. The "interannual" time series have periods of one year and longer, lacking only the stationary harmonic seasonal cycles.

[14] The above procedure characterizes the average variance for each of the timescales over the region as a whole. Legaard and Thomas [2006, 2008] take a complementary approach, characterizing the seasonal, interannual and intraseasonal variability at each grid point for SST and CHL.

\section{Results}

\subsection{Temporal Mean Fields}

[15] In this section we present the basic characteristics of the overall temporal means for the four variables. These are examined in greater detail later in the manuscript. 

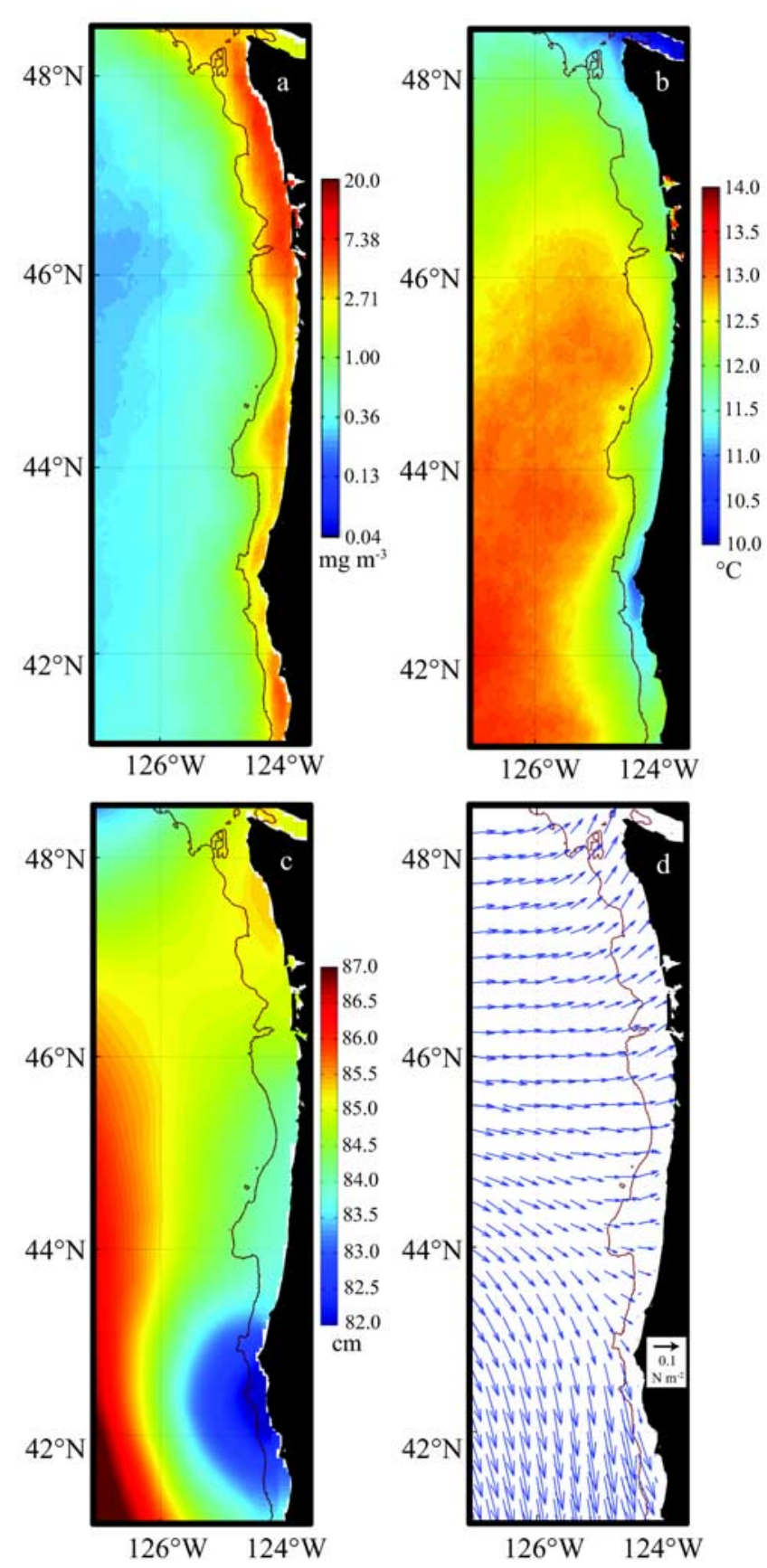

Figure 2. Eight-year mean of (a) chlorophyll pigment concentration in $\mathrm{mg} \mathrm{m}^{-3}$, (b) sea surface temperature in ${ }^{\circ} \mathrm{C}$, (c) sea surface dynamic height derived as a long-term mean dynamic topography in $\mathrm{cm}$, with reference to $500 \mathrm{~m}$ and derived from Levitus et al. [1998] climatology, and (d) six-year mean of QuikSCAT wind stress (TAU) in $\mathrm{N} \mathrm{m}^{-2}$.

[16] The eight-year mean CHL distribution (Figure 2a) shows a strong onshore/offshore pattern, with a maximum concentration near the coast, decreasing offshore (Figure 2a). The $200 \mathrm{~m}$ isobath generally lies just offshore of a coastal region of concentrations higher than $5 \mathrm{mg} \mathrm{m}^{-3}$ north of $\sim 45^{\circ} \mathrm{N}$, while south of $\sim 45^{\circ} \mathrm{N}$ the coastal concentrations reach a maximum of $3.5 \mathrm{mg} \mathrm{m}^{-3}$. Offshore of the $200 \mathrm{~m}$ isobath, an intermediate band of $\sim 150 \mathrm{~km}$ width contains values between 0.3 and $2.5 \mathrm{mg} \mathrm{m}^{-3}$; farther offshore concentrations decrease to below $0.2 \mathrm{mg} \mathrm{m}^{-3}$. These regions approximately coincide with offshore zones described by others [e.g., Kahru and Mitchell, 2000; Legaard and Thomas, 2006; Henson and Thomas, 2007]. Higher values over the shelf in the north may be partially due to material other than chlorophyll originating from estuaries and the Columbia River.

[17] Cold coastal and warm oceanic temperatures characterize the SST temporal mean field (Figure 2b), consistent with those described by Legaard and Thomas [2006] and others. The coldest SST values occur close to the coast around and southwest of Cape Blanco and north of Grays Harbor $\left(47.0^{\circ} \mathrm{N}\right)$ over the shelf and in the Juan de Fuca Straight $\left(48.2^{\circ} \mathrm{N}, 124^{\circ} \mathrm{W}\right)$, while warm offshore water occurs south of $\sim 47^{\circ} \mathrm{N}$ (Figure $2 \mathrm{~b}$ ). SST shows the influence of an equatorward summer jet along the $200-\mathrm{m}$ isobath around Heceta Bank, with colder water inshore of the isobath and jet.

[18] As noted above, the mean SSDH relative to $500 \mathrm{~m}$ (see Levitus et al. [1998] and Figure 2c) is calculated and added to the SSH anomalies as a coarse proxy for the temporal mean SSH field. In Figure $2 \mathrm{c}$ these data (on a $1^{\circ}$ grid) have been mapped to the same grid as the other variables. Although these data are highly smoothed, the mean dynamic height field shows lower values around Cape Blanco and extending north along the Oregon Shelf, consistent with the wider regions of low SST in southern part of the domain (Figure $2 b$ ). The contribution of this SSH to the altimeter fields is a general downward slope toward the coast south of the Columbia River, consistent with an equatorward current, and a downward slope toward the northwest off the coast of Washington, depicting onshore flow of the North Pacific Current off southern Washington and poleward flow off northern Washington.

[19] The six-year TAU temporal mean (Figure 2d) shows downwelling-favorable winds north of the Columbia River $\left(\sim 46.2^{\circ} \mathrm{N}\right)$ and upwelling-favorable winds south of $44.0^{\circ} \mathrm{N}$. Between $44^{\circ}$ and $46^{\circ} \mathrm{N}$, the temporal mean of the wind is mostly onshore and upwelling-neutral, with a slightly northward component over the shelf.

\subsection{Seasonal Climatology Fields}

[20] The eight-year (1998-2005) bimonthly CHL seasonal climatology (Figure 3) depicts maximum concentrations inshore of the 200-m isobath in summer. These values decrease in winter, especially south of the Columbia River $\left(\sim 46.2^{\circ} \mathrm{N}\right)$. North of the Columbia River, moderately high concentrations continue to be seen in winter over the shelf. Individual monthly means for December and January (not shown) display the narrowest bands of elevated CHL concentrations next to the coast, with the lowest values found during the year (maxima less than $3 \mathrm{mg} \mathrm{m}^{-3}$ ). These values may reflect a contribution from $\mathrm{CDOM}$ and particulate matter from the large estuaries and the Columbia River Plume, which flows northward in winter, trapped over the shelf by onshore Ekman transport [Hickey, 1998; Thomas et al., 2003]. Evidence for this is provided by Thomas and Weatherbee [2006], who show maps of normalized $555 \mathrm{~nm}$ water leaving radiances, an indicator of particulate matter. Their winter patterns are very similar to the winter surface CHL distributions presented here. 

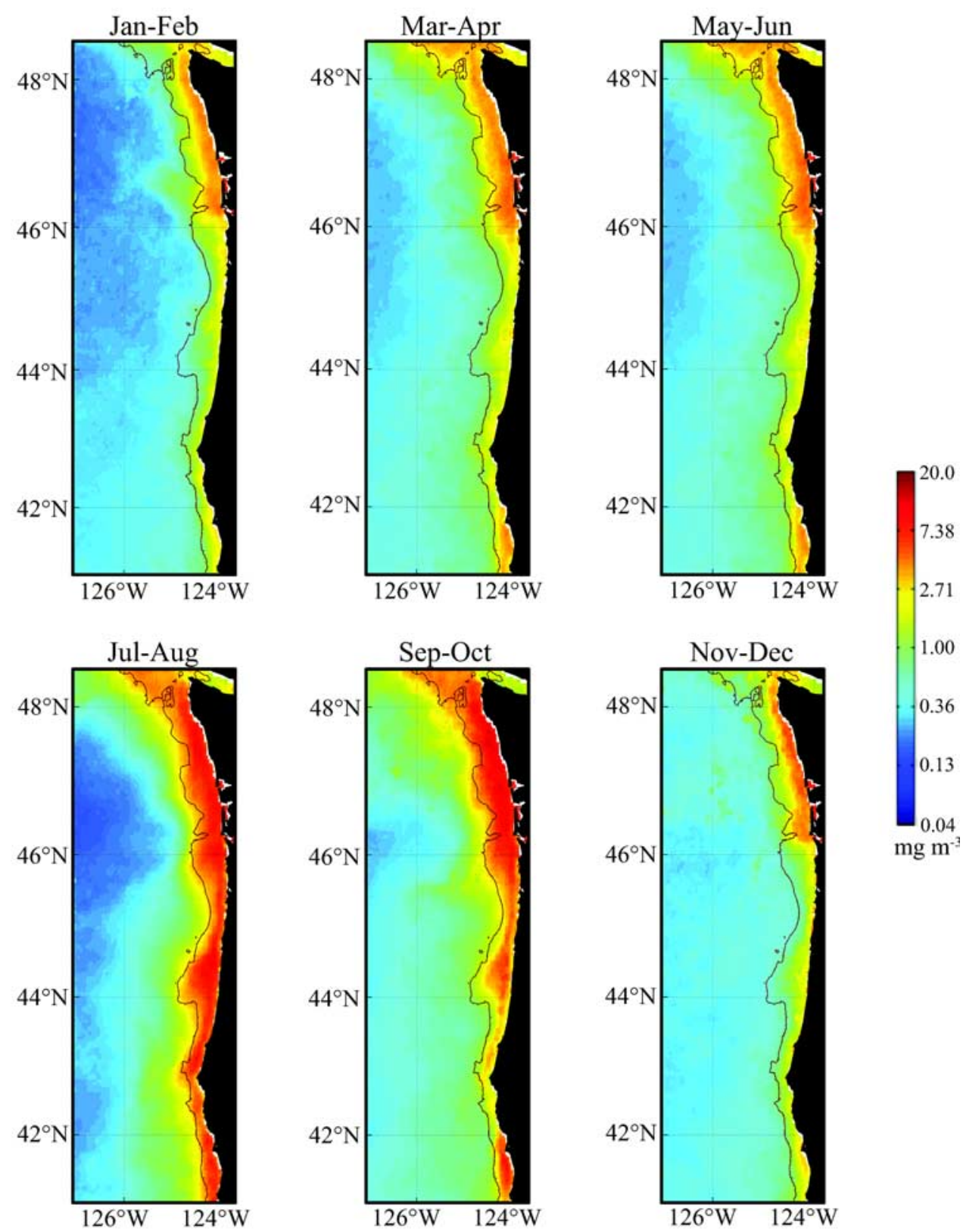

Figure 3. Climatological fields of chlorophyll pigment concentration in $\mathrm{mg} \mathrm{m}^{-3}$ from January 1998 to December 2005. The 200-m isobath is shown here and in other figures for reference to shelf geometry.

[21] South of the Columbia River, a relatively wide region of higher CHL concentration occurs near Heceta Bank and south of Cape Blanco in spring, summer and autumn. Individual monthly $\mathrm{CHL}$ variance fields (not shown) in spring and summer contain extensions of higher chlorophyll variance reaching as far as $126^{\circ} \mathrm{W}$, near $45.5^{\circ} \mathrm{N}, 44.25^{\circ} \mathrm{N}$ and $43.0^{\circ} \mathrm{N}$. We associate these extensions with episodic higher concentrations due to mesoscale circulation features offshore of the Columbia River, Heceta Bank and Cape Blanco. Over the narrow shelf between $\sim 44.50$ and $45.50^{\circ} \mathrm{N}$, the coastal band of higher CHL is also narrow and low in variance (not shown) for most of the year, reflecting a lack of meandering and eddy activity (see below). CHL variance fields presented by Legaard and Thomas [2008, Figures 8 and 9] also reveal low values of variance in this region.
[22] The SST seasonal climatology (Figure 4) reflects strong poleward flow along and offshore of the shelf break that carries warm water during December, January, and February, while the Columbia River fills in cold water over the shelf region north of its outfall (Figure 4, JanuaryFebruary, north of $46.2^{\circ} \mathrm{N}$ ). An increase in offshore SST starts in March, with a peak in August-September and a minimum in January-February. Upwelling conditions start in March-April around Cape Blanco. Between June and September the Columbia River contributes relatively warm water to the coastal zone. The SST on Heceta Bank decreases between June and October, reaching temperatures $<10.0^{\circ} \mathrm{C}$ at times, while at Cape Blanco cold water crosses the shelf break and extends offshore in summer. These fields are consistent with patterns shown by Legaard and 

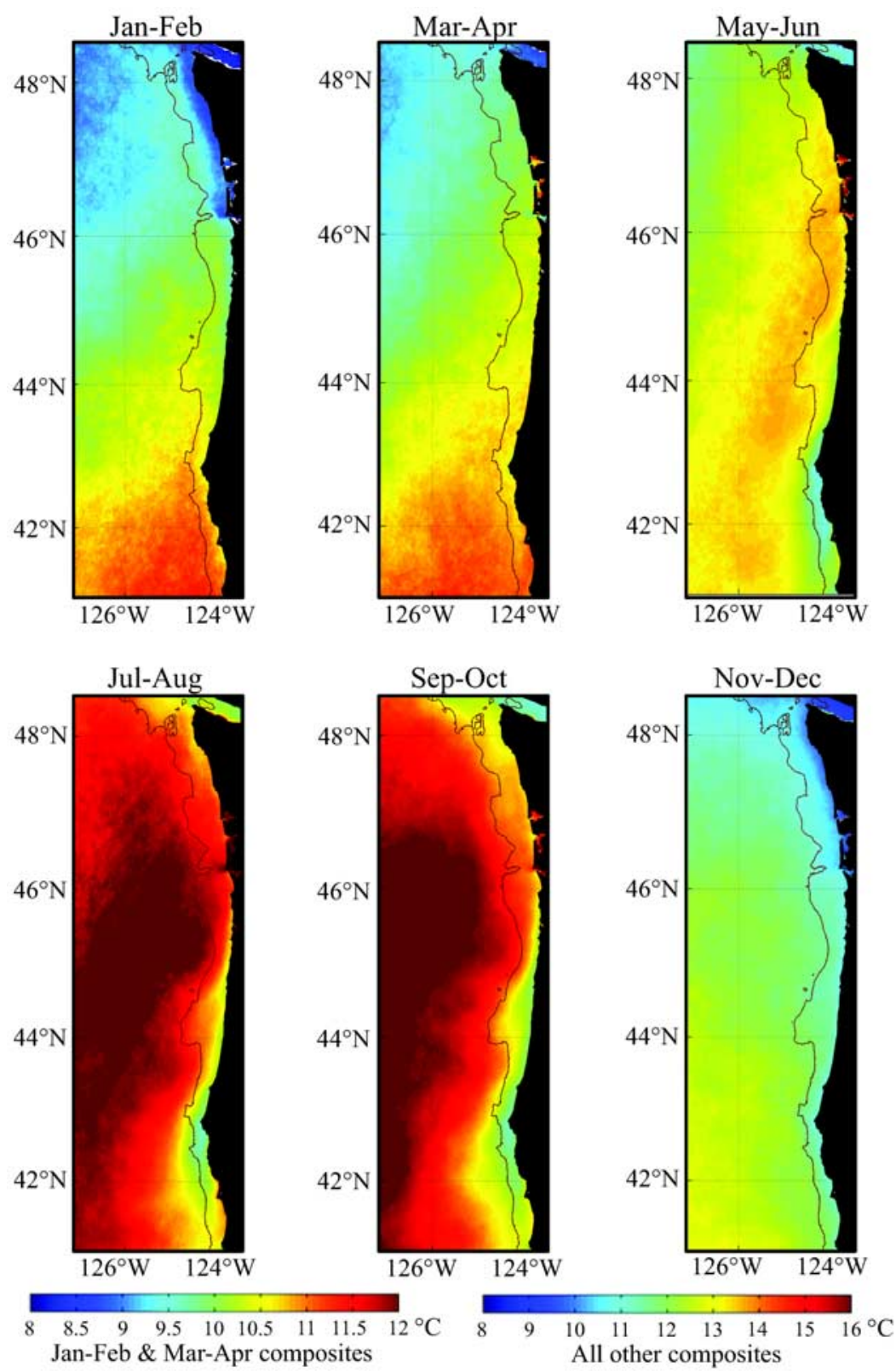

Figure 4. Climatological fields of sea surface temperature from January 1998 to December 2005. Note that the color bar associated with the January-February and March-April fields (left color bar) is different than associated with other months (right color bar) in order to show the tongue of warmer water moving northward along the $200-\mathrm{m}$ isobath during winter.

Thomas [2006] but show more details of the seasonal fields. Plots of SST variance (not shown) demonstrate strong variability in SST during July-September, especially over Heceta Bank and southwest of Cape Blanco, suggesting strong mesoscale variability around these topographic features. SST variance fields (not shown) in the region of the narrow shelf between $44.5^{\circ}$ and $45.5^{\circ} \mathrm{N}$ are low (similar to CHL variances), as also shown by Legaard and Thomas [2008].

[23] The SSH seasonal climatology (Figure 5) is composed of the harmonic seasonal variability from the altimeter data and the long-term mean SSDH field relative to $500 \mathrm{~m}$ (Figure 2c).This mean field is low next to the coast and high offshore, especially south of $46^{\circ} \mathrm{N}$. Thus the high sea level next to the coast from November to February comes entirely from the altimeter data, depicting the effects of winter downwelling, onshore Ekman transport, and incorporation of less dense water from coastal sources. These factors contribute to a poleward direction of the northern California Current during winter. The opposite situation occurs from May to October, when the slope of SSH is downward toward the coast owing to offshore-Ekman transport. Both the poleward (winter) and the equatorward (summer) surface flow are affected by the bathymetry of Heceta Bank, meandering around the bank in both directions.

[24] North of the Columbia River, SSH variances (not shown) are extremely high over the shelf from November through April, reflecting the response to the passage of storms. High SSH variances also occur south of Cape 

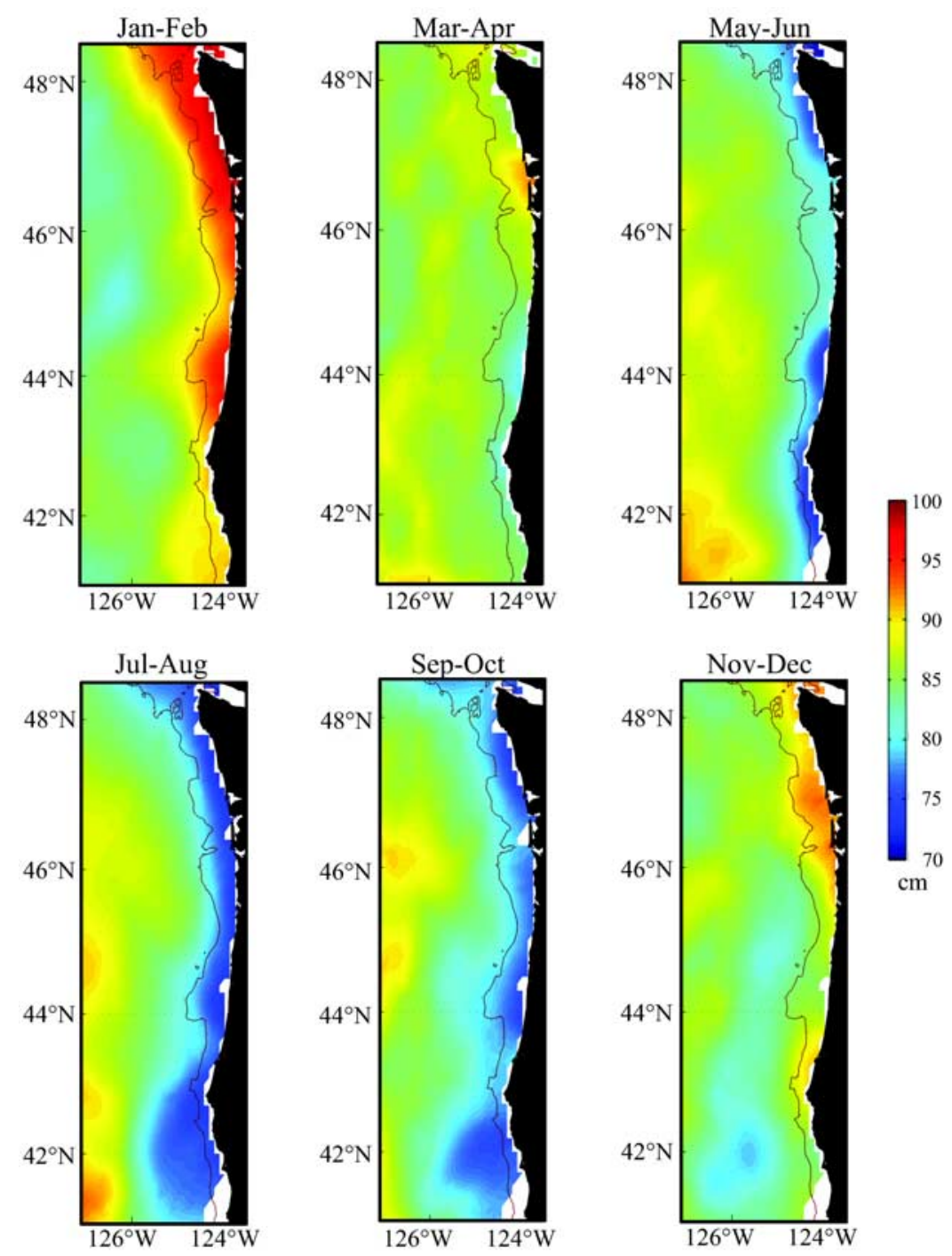

Figure 5. Climatological of fields of sea surface height in centimeters from January 1998 to December 2005. The dynamic height field from Figure $2 \mathrm{c}$ is combined with the altimeter harmonic seasonal cycle.

Blanco from July to November, the period when the equatorward jet separates near Cape Blanco, creating a vigorous field of mesoscale eddies. Similar to CHL and SST, the variance of SSH over the narrow shelf region between $\sim 44.5^{\circ}$ and $45.5^{\circ} \mathrm{N}$ is low during most of the year, consistent with a fairly steady and narrow coastal jet.

[25] The ocean vector wind stress seasonal climatology (six years, 2000-2005; Figure 6) shows well known patterns [e.g., Bakun and Nelson, 1991; Hill et al., 1998] but with more detail and much more certainty than climatologies constructed from sparse merchant ship data [Bakun and Nelson, 1991]. The fields depict winter downwelling conditions (November-February), and summer (May-August) upwelling conditions. Downwelling conditions start in October in the north, and by December and January extend along the entire study region, strongest in the north. In March, upwelling starts south of $\sim 43^{\circ} \mathrm{N}$ and southward winds dominate in the entire area during May-August, strongest in the south. Between 44 and $46^{\circ} \mathrm{N}$, the nearly eastward wind stress vectors in the long-term mean (Figure 2d) are produced by the alternation between a four-month period
(November-February) of strong poleward winds and a six-month period (May-October) of moderate equatorward winds.

\subsection{Empirical Orthogonal Functions of Nonseasonal Fields}

[26] The stationary harmonic seasonal cycles are removed from the time series at each spatial grid point to create nonseasonal anomalies for all variables and the dominant time/space patterns in these are summarized by EOF decompositions. The EOF time series include intra-annual variability (timescales of one month to a year) and interannual variability (timescales of one year and more, lacking the stationary annual cycle). The interannual variability also includes the nonstationary part of the annual cycle, i.e., interannual changes in the timing of seasonal transitions.

[27] The first two CHL EOF modes explain $37.3 \%$ of the nonseasonal variance. The first CHL mode represents $27.1 \%$ of the variance (Tables $1-4$; Figures $7 \mathrm{a}$ and $8 \mathrm{a}$ ) and depicts maximum values inshore of the $200-\mathrm{m}$ isobath north of $46^{\circ} \mathrm{N}$ and over the Heceta Bank region. Coastal 

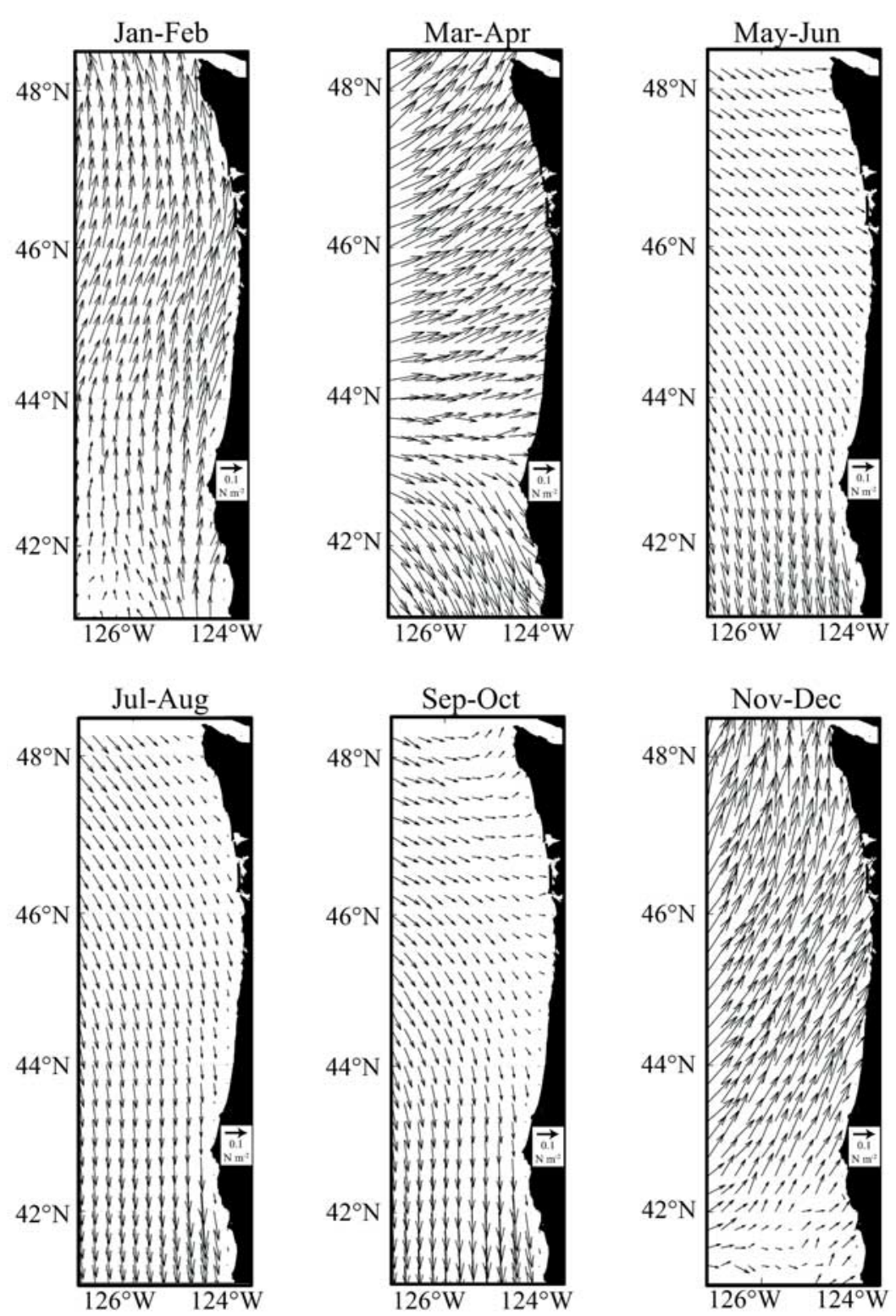

Figure 6. Climatological fields of wind stress in $\mathrm{N} \mathrm{m}^{2}$ from January 2000 to December 2005.

values decrease from north to south and are lower farther offshore. One difference between the first EOF spatial pattern (Figure 7a) and the mean summer field (Figure 3) is the relatively lower EOF signal in the region of the narrow shelf between $44.5^{\circ}$ and $45.5^{\circ} \mathrm{N}$. The signal weighting for this area is also weak in EOF 2 (Figure 9a), consistent with a lack of variance in this region. The lowpassed time series (Figure 8a) for the first mode shows the

Table 1. Spatial Means of Temporal Variances of Wind Stress, Surface Chlorophyll Concentration, Sea Surface Temperature, and Sea Surface Height in Original 16-Day Data ${ }^{a}$

\begin{tabular}{lcccc}
\hline & TAU-v, $\%$ & CHL, $\%$ & SST, \% & SSH, \% \\
\hline Seasonal mean & 30 & 38 & 81 & 24 \\
Nonseasonal mean & 70 & 62 & 19 & 76 \\
\hline
\end{tabular}

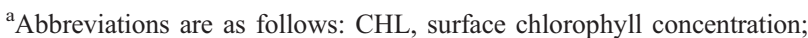
SSH, sea surface height; SST, sea surface temperature; TAU-v, wind stress $\mathrm{v}$ component. coastal CHL represented by the spatial pattern is higher during the middle of the record (2001-2003) and lower during the beginning (1998-2000) and end of the time series (2004-2005). The second EOF mode of CHL (10.2\%

Table 2. Nonseasonal Temporal Variances From Wind Stress, Surface Chlorophyll Concentration, Sea Surface Temperature, and Sea Surface Height From the Empirical Orthogonal Function Time Series $^{\mathrm{a}}$

\begin{tabular}{lcccc}
\hline & TAU-v, $\%$ & CHL, $\%$ & SST, $\%$ & SSH, \% \\
\hline EOF 1 & 61.5 & 27.1 & 65.8 & 22.2 \\
EOF 2 & - & 10.2 & 7.9 & 8.6 \\
Total & 61.5 & 37.3 & 73.7 & 30.8 \\
\hline
\end{tabular}

${ }^{\text {a }}$ The total variance explained is assumed to be the $100 \%$ of variance explained on the next decomposition analysis. Abbreviations are as follows: CHL, surface chlorophyll concentration; EOF, empirical orthogonal function; SSH, sea surface height; SST, sea surface temperature; TAU-v, wind stress $\mathrm{v}$ component. 
Table 3. Variance Decomposition Explained by a Single "Coastal" Empirical Orthogonal Function 1 and $2^{\mathrm{a}}$

\begin{tabular}{lccccc}
\hline & \multicolumn{3}{c}{ EOF 1 } & & EOF 2 \\
\cline { 2 - 4 } & TAU-v, \% & CHL, \% & SSH, \% & & SST, \% \\
\hline Decadal & 0.1 & 7.7 & 4.0 & 1.2 \\
Interannual & 9.4 & 10.1 & 61.0 & 21.5 \\
Intra-annual & 90.5 & 82.2 & 35.0 & 77.3 \\
\hline
\end{tabular}

${ }^{a}$ Abbreviations are as follows: CHL, surface chlorophyll concentration; EOF, empirical orthogonal function; SSH, sea surface height; SST, sea surface temperature; TAU-v, wind stress v component.

of nonseasonal variance) shows out-of-phase pigment concentration variability north and south of $\sim 46^{\circ} \mathrm{N}$ (Figure 9a). The time series for this mode (Figure 10a) suggests positive anomalies in the northern region (often in midyear) during 1998-2001 and positive anomalies in the southern region (again with some preference for midyear) from mid-2001 through the end of 2005 (looking at the unfiltered time series in Figure 10a). These features are examined in more detail in the Discussion section, as are specific features in the time series of the other EOF's.

[28] Most of the nonseasonal SST variability is captured by the first two EOF modes, which account for $73.7 \%$ of the nonseasonal variability (Table 2). The first SST mode $(65.8 \%$ of variance, Figures $7 \mathrm{~b}$ and $8 \mathrm{~b})$ emphasizes the offshore region, with the highest amplitudes in a wide region west of $125^{\circ} \mathrm{W}$, between $44^{\circ}$ and $48^{\circ} \mathrm{N}$. Next to the coast, amplitudes are moderately lower south of the Columbia River, especially in a region $\sim 100-\mathrm{km}$ wide south of Cape Blanco. The first mode time series has an upward trend and strong quasi-annual signals at the beginning and end of the record. The second mode SST spatial pattern (Figure 9b) represents the more coastal SST signal off Oregon, since it is strongly positive in a "coastal" wedge that is narrow near the Columbia River $\left(46.2^{\circ} \mathrm{N}\right)$ and widens to the south. The quasi-annual nature of the SST EOF time series (Figure 10b) represents modulations of the annual cycle's timing and strength, as explained in the Discussion section. The net result of the two SST modes is a general interannual warming of offshore waters during the record (with especially cool conditions in mid-1998 and 1999), along with a coincident warming of the region in a coastal wedge that expands south of the Columbia River.

[29] The first two SSH EOF modes account for $30.8 \%$ of the nonseasonal variance (Table 2). The first mode spatial pattern (Figure 7c, 22.2\% of the nonseasonal variance) consists of high SSH inshore (poleward flow), decreasing somewhat south of Cape Blanco $\left(\sim 43.0^{\circ} \mathrm{N}\right)$. The time series (Figure 8c), shows positive SSH anomalies next to the coast in winter or autumn, except during 2000-2001. This is consistent with the winter SSH climatology when the time

Table 4. Variance Decomposition Explained by Using Both Empirical Orthogonal Functions 1 and $2^{\mathrm{a}}$

\begin{tabular}{lccc}
\hline & CHL, \% & SST, \% & SSH, \% \\
\hline Decadal & 8.3 & 18.5 & 5.2 \\
Interannual & 12.0 & 46.1 & 61.5 \\
Intra-annual & 79.7 & 35.4 & 33.3 \\
\hline
\end{tabular}

${ }^{a}$ Abbreviations are as follows: CHL, surface chlorophyll concentration; $\mathrm{SSH}$, sea surface height; SST, sea surface temperature. series is positive and consistent with summer SSH conditions when it is negative. The second $\mathrm{SSH}$ mode $(8.6 \%$ of the nonseasonal variance, Figure $9 \mathrm{c}$ and 10c) is strongest in the southern half of the domain, representing low sea level offshore of higher sea level over the coast (implying poleward flow when the time series is positive). The offshore low region has a somewhat "eddy-like" structure, with centers offshore of Heceta Bank $\left(43.0^{\circ}-45.0^{\circ} \mathrm{N}\right)$ and $\mathrm{SE}$ of Cape Blanco. When the time series is negative, it represents stronger equatorward flow. Negative values may also indicate a strengthening of offshore anticyclonic eddies or a weakening of cyclonic eddies in the same locations.
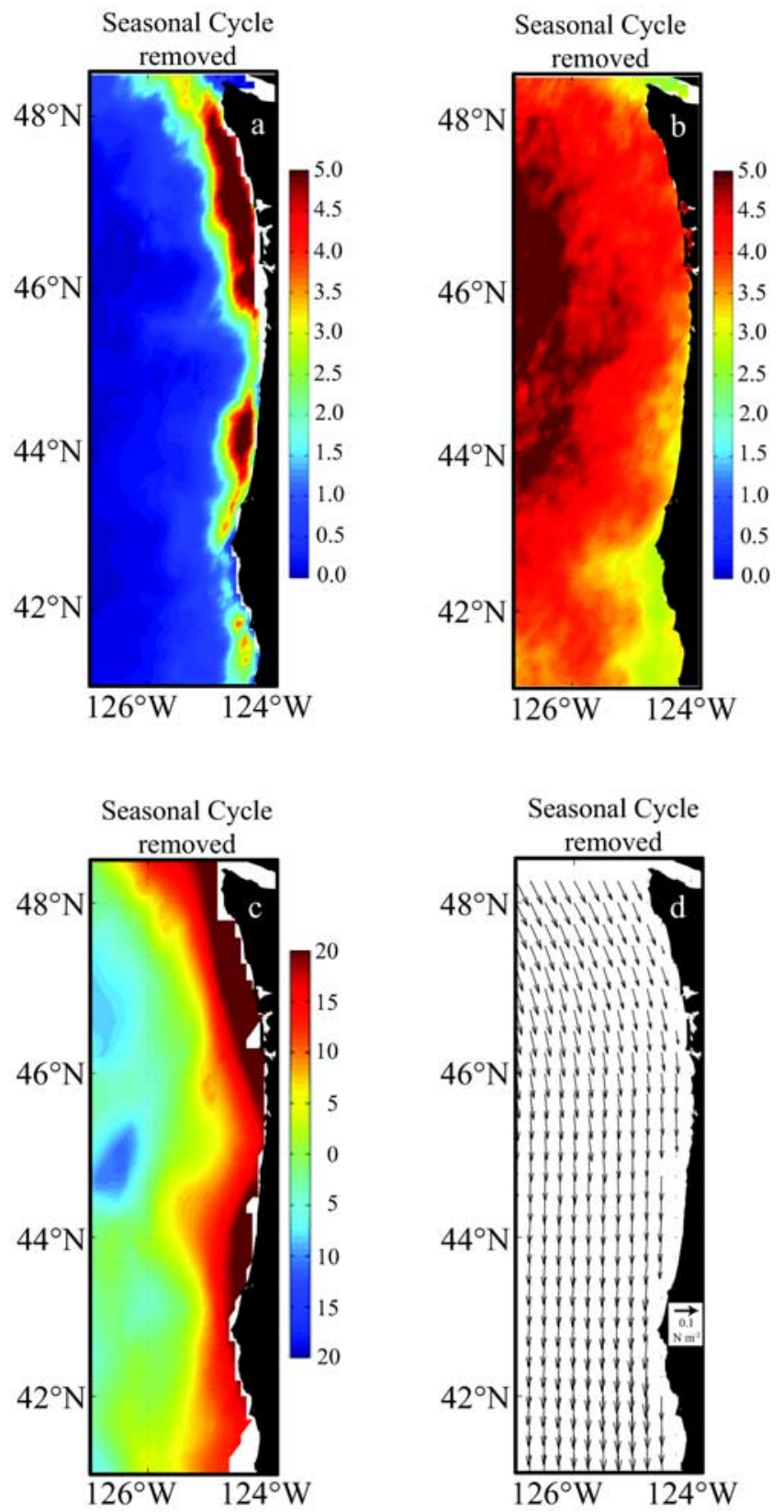

Figure 7. Spatial patterns of the first empirical orthogonal function mode of (a) surface chlorophyll concentration in $\mathrm{mg} \mathrm{m}^{3}$, (b) sea surface temperature in ${ }^{\circ} \mathrm{C}$, (c) sea surface height in $\mathrm{cm}$; and (d) wind stress in $\mathrm{N} \mathrm{m}^{-2}$. 

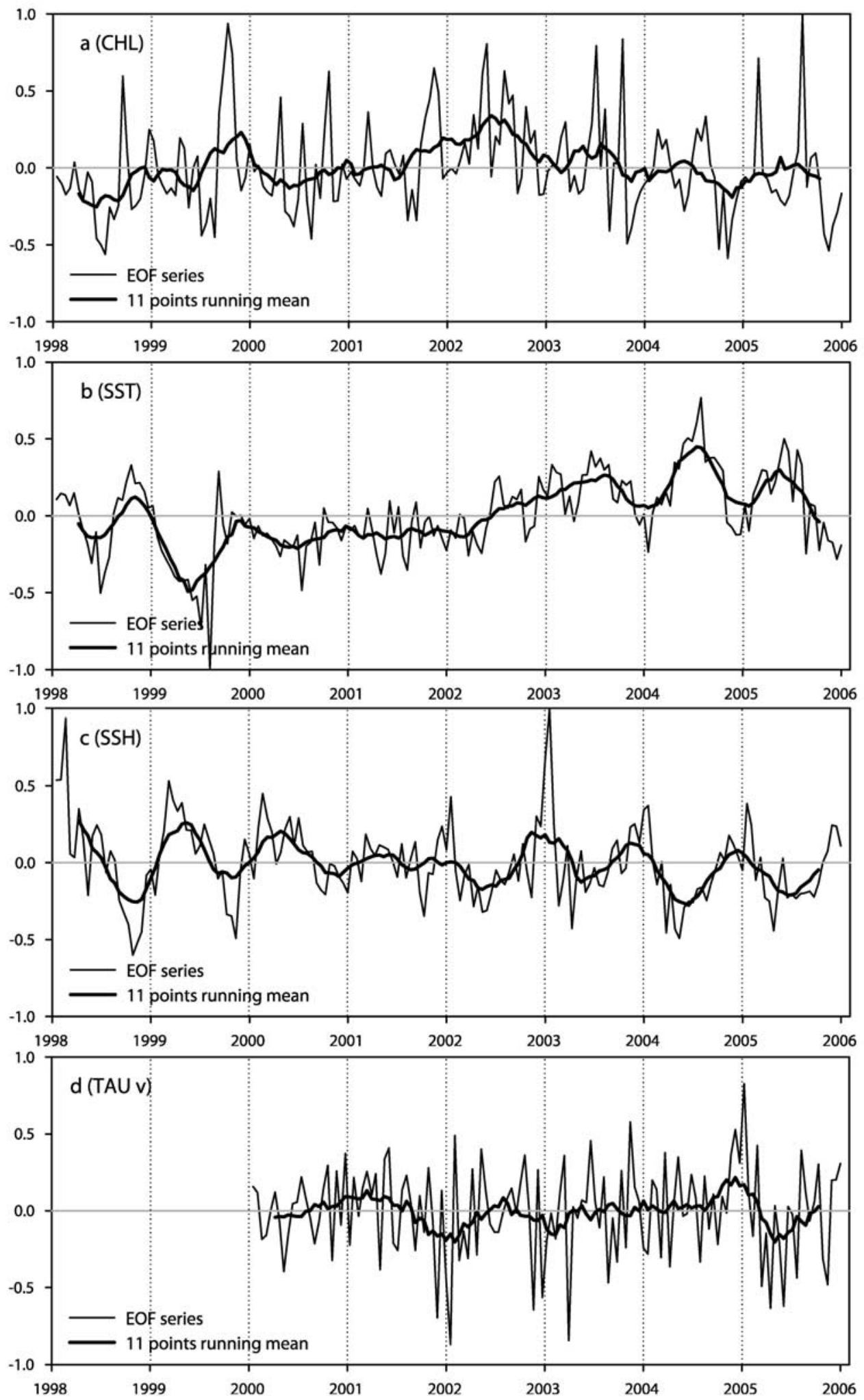

Figure 8. Time series for the first empirical orthogonal function mode of (a) surface chlorophyll concentration (CHL), (b) sea surface temperature (SST), (c) sea surface height (SSH), and (d) wind stress (TAU). The 11-point (176-day) running mean (dark lines) suppresses signals with timescales less than a year and represents interannual variability, while the unfiltered time series (light lines) represents both intra-annual and interannual variability. 

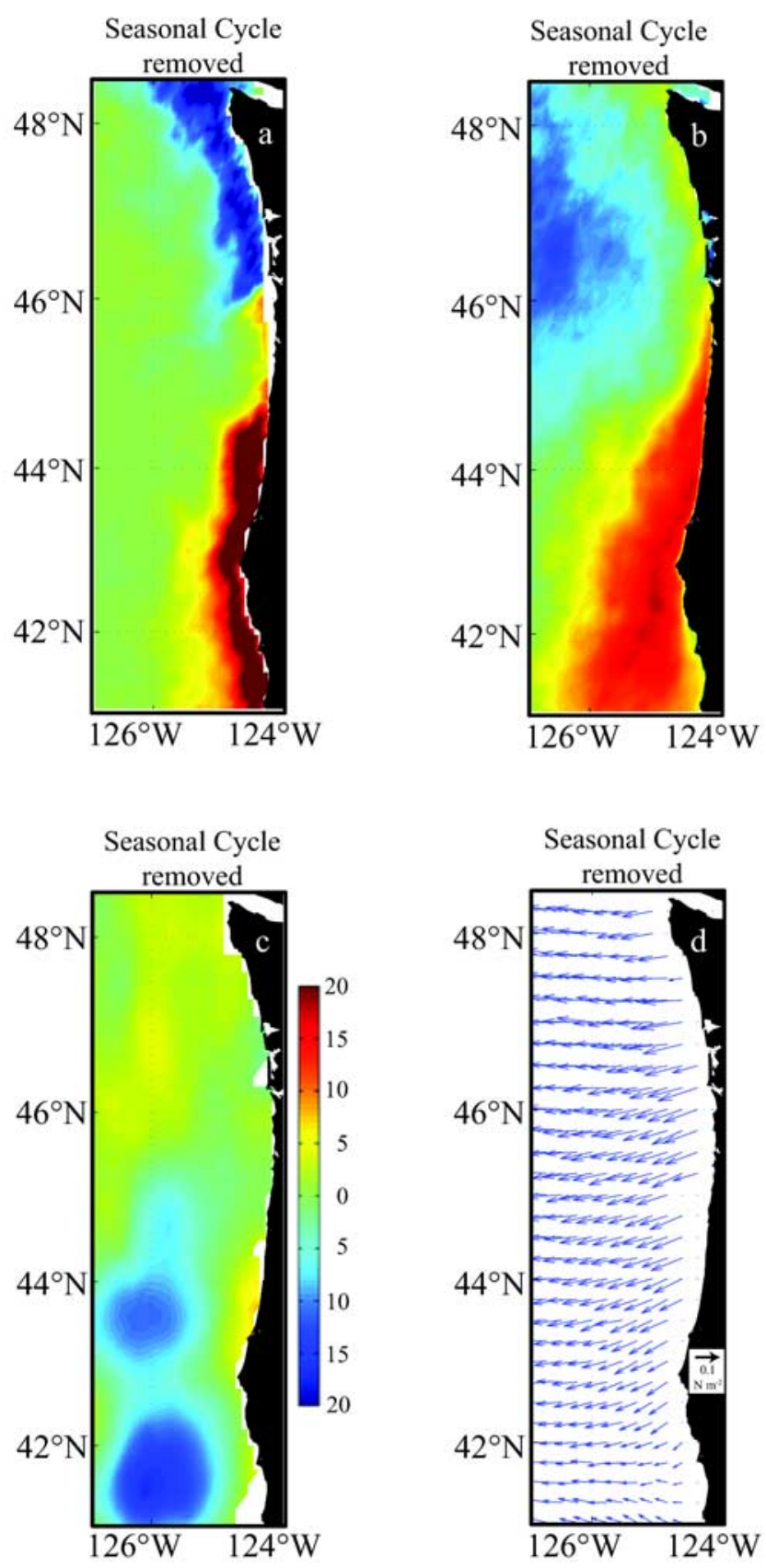

Figure 9. Spatial patterns of the second empirical orthogonal function mode of (a) surface chlorophyll concentration in $\mathrm{mg} \mathrm{m}^{3}$, (b) sea surface temperature in ${ }^{\circ} \mathrm{C}$, (c) sea surface height in $\mathrm{cm}$, and (d) wind stress in $\mathrm{N} \mathrm{m}^{-2}$.

Anticyclonic eddies have been observed in these regions in surveys during the summer of 2000 [Barth et al., 2005] and the winter of 2003 (M. Saraceno, personal communication, 2007).

[30] The first two EOF modes of TAU explain $74.8 \%$ of the nonseasonal variance and separate the two orthogonal components of the wind stress (Table 2). The spatial pattern in the first mode represents the N-S component (Figure 7d), showing upwelling and downwelling-favorable conditions in the entire area, qualitatively similar to the July-August climatological field. The first EOF $(61.5 \%$ of the nonseasonal variance) time series is mostly intra-annual in nature (Figure 8d). The second mode of TAU represents the eastwest component of the wind stress over the entire area (Figure 9d) and is again more intraseasonal in nature. The primary signal of this mode $(13.3 \%$ of the nonseasonal variance, Figure 10d) is a period of relatively stronger onshore winds in the winter of 2001-2002.

\subsection{Division of Temporal Variability Into Intra-annual, Interannual, and Decadal}

[31] Tables 1-4 present the percent of variability associated with each timescale, calculated as described in the methods section. In general, Table 1 shows that the nonseasonal variability is greater than the seasonal variability, with the exception of SST, which experiences strong seasonal heating and cooling in regions off the shelf. A similar pattern would be evident for SSH, except that we remove spatial means before forming the 16-day $\mathrm{SSH}$ fields to remove residual orbit error. This also removes most seasonal variability of offshore steric heights caused by seasonal heating, leaving the dynamic gradients in SSH. The net result is that over $60 \%$ of the variability is nonseasonal for alongshore TAU, surface CHL and SSH gradients. For SST, the seasonal cycle is weakest over the shelf [Legaard and Thomas, 2006], where summer upwelling counteracts surface heating. Thus, although only $19 \%$ of the SST signal (averaged over the entire domain) is included in the nonseasonal EOF analysis, this signal is primarily from the coastal upwelling region of interest. Using a different type of analysis (a point by point decomposition into intraseasonal, seasonal and interannual variance for each 18- $\times$ 18-km pixel), Legaard and Thomas [2006, 2008] find that $20-40 \%$ of the total variance is contributed by the intraseasonal variability over Heceta Bank and southwest of Cape Blanco, with $15-20 \%$ contributed by the interannual signal in the $200 \mathrm{~km}$ next to the coast off Oregon. Thus nonseasonal variability accounts for $35-60 \%$ of the total variance in the regions of strongest upwelling.

[32] When the single EOF associated with the coastal signal is considered (Table 3), intra-annual variability accounts for most of the coherent nonseasonal variability for the alongshore TAU, SST and surface CHL. Interannual variability accounts for the majority of the SSH nonseasonal variability. When the first two EOF's are summed (Table 4), results for surface $\mathrm{CHL}$ and $\mathrm{SSH}$ remain unchanged; nonseasonal surface CHL is primarily intra-annual and $\mathrm{SSH}$ is primarily interannual. For SST, inclusion of both EOFs moves more of the nonseasonal variance into the decadal and interannual scales, owing to the long-term trend and the quasi-annual signals at the beginning and end of the record for offshore SST (EOF 1).

[33] Correlations between the EOF time series help to complete the picture. On intra-annual time series, the 16-day data points in each time series are nearly independent (decorrelation scales are 16-32 days), providing a relatively large number $(\sim 70-100)$ of degrees of freedom for the 6-8 year records and resulting in significant correlations (at the $95 \%$ level) of approximately $\mathrm{r}=0.2$. The highest correlation in the intra-annual time series is between the SST EOF 2 and CHL EOF $1(\mathrm{r}=-0.55)$. This simply confirms that the coastal signals of cold SST and high CHL covary significantly on short (weeks to months) timescales. 

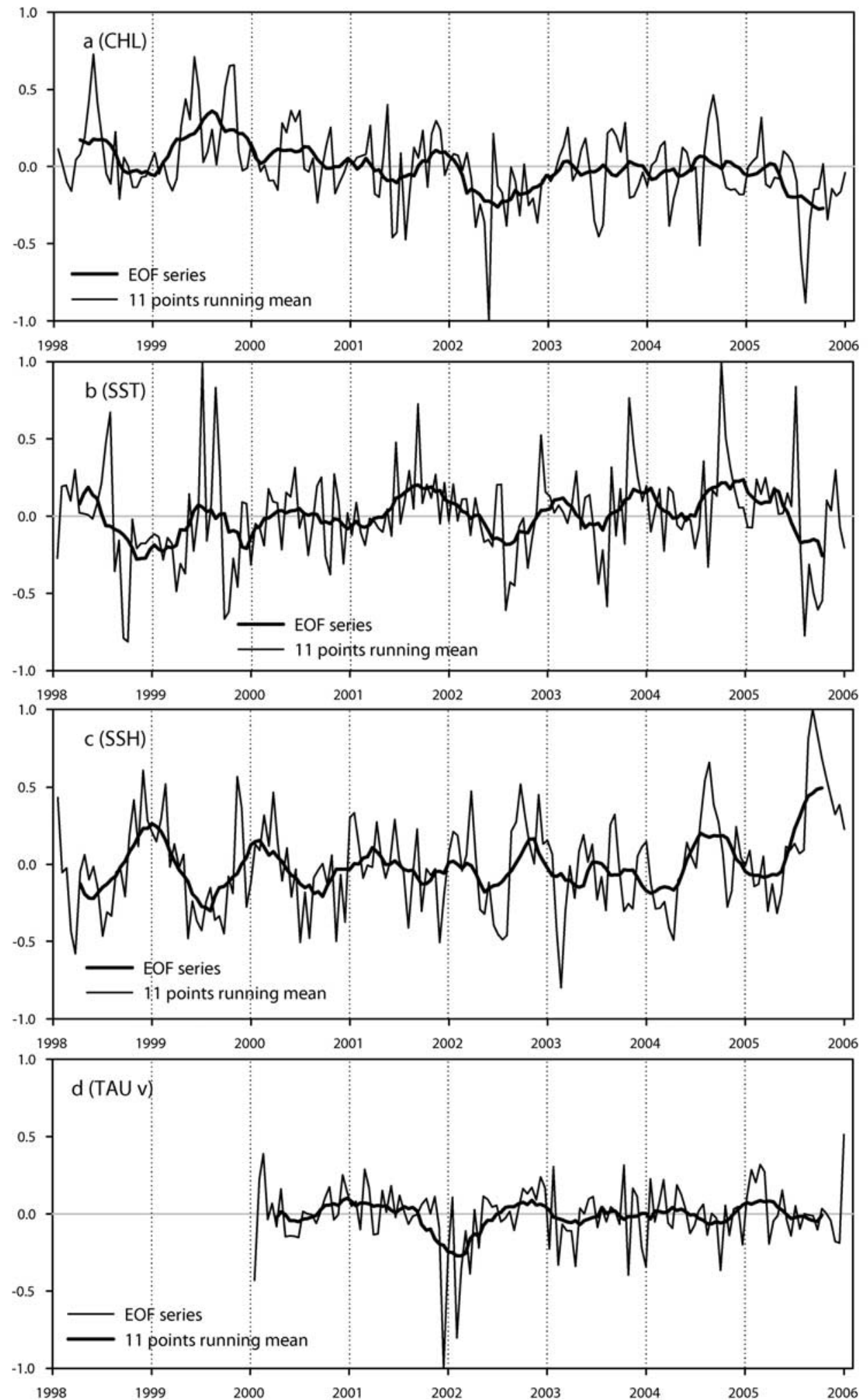

Figure 10. Time series for the second empirical orthogonal function mode of (a) surface chlorophyll concentration (CHL), (b) sea surface temperature (SST), (c) sea surface height (SSH), and (d) wind stress (TAU). The 11-point (176-day) running mean (dark lines) represents interannual variability while the unfiltered time series (light lines) represents both intra-annual and interannual variability. 
This variability is presumably driven by winds but we find marginal correlations between the intra-annual time series of southward alongshore TAU and the other variables at zero lag: CHL EOF $1(\mathrm{r}=+0.30)$, SST EOF $2(\mathrm{r}=-0.21)$ and SSH EOF $1(r=-0.19)$. Correlations drop to near zero at lags of 1-2 time step (16-32 days). Although the significance level and amount of variance explained are low, these correlations are consistent with expected relationships in upwelling systems on timescales of weeks to months. Note that the synoptic scale ( $3-10$ days) is not resolved by the 16-day composites/averages used in this study.

[34] On interannual timescales, the time series are dominated by residual quasi-annual signals discussed further below, which result in long decorrelation timescales and a small number of degrees of freedom. Lagged correlation coefficients are cyclical, making it difficult to assign statistical reliability. With this caveat, the highest correlations with minimal lags are as follows: CHL EOF 1 and SST EOF 2 (-0.56, lag of 16 days); CHL EOF 1 and SSH EOF 1 (-0.52, lag of 16 days); SST EOF 2 and SSH EOF 1 $(+0.58$, lag of 32 days); and CHL EOF 2 and SST EOF 2 $(-0.54$, zero lag). No significant correlations between alongshore TAU and the other variables were present at lags of 0 to 48 days. There are higher correlations at longer lags between TAU EOF 1 and the other variables, but they make little physical sense: CHL EOF $1(-0.43$, lag of two months); SST EOF 2 (+0.52, lag of 4 months); SSH 1 $(-0.21$, lag of 5 months $)$.

\section{Discussion}

\subsection{Spatial Variability: Two Major Dynamical Regions} and Their Annual Cycles

[35] In general, the patterns of coastal CHL are consistent with previous views of the large-scale chlorophyll patterns along the northern California Current [Strub et al., 1990; Thomas and Strub, 1989, 1990, 2001; Thomas et al., 1994, 2001, 2003; Legaard and Thomas, 2006], where high CHL values are evident north of $46^{\circ} \mathrm{N}$, with seasonal maxima in spring and summer and minima in winter (Figure 3 ). Extending this to SSH, SST and alongshore TAU, we find spatial and temporal patterns that divide this domain into two dynamic northern and southern regions, separated somewhere between Cape Blanco and the mouth of the Columbia River $\left(43-46^{\circ} \mathrm{N}\right)$, depending on the variable considered.

[36] Considering surface forcing, upwelling-favorable winds (Figure 6) begin first in spring south of Cape Blanco, spreading to the north in summer; downwelling-favorable winds begin first in autumn north of the Columbia River, extending to the south in winter. The fields of SSH (Figure 5) next to the coast follow this forcing fairly directly, dropping first south of $45^{\circ} \mathrm{N}$ in March-April and rising first north of $45^{\circ} \mathrm{N}$ in November-December. The largest region of low $\mathrm{SSH}$ is around and south of Cape Blanco, where there are eight months of upwelling-favorable and four months of downwelling-favorable TAU. The offshore movement of the $\mathrm{SSH}$ gradient corresponds to the offshore movement and separation from the coast of the equatorward jet in summer [Barth et al., 2000; Strub and James, 2000].

[37] One of the new and interesting aspects of the SSH analysis is the degree to which it confirms the topographic control of both poleward and equatorward flow around the Heceta Bank region. Previous studies have demonstrated the topographic deflection of the equatorward summer jet by capes and subsurface topography [Haidvogel et al., 2001; Barth et al., 2005; Castelao et al., 2005]. Haidvogel et al. [1991] modeled this deflection around an idealized cape for equatorward flow, but also found a deflection of the mean flow around the cape for poleward flow. The mean altimeter SSH fields in winter are consistent with this model result. The model also shows that the deflection of the poleward flow in winter produces filaments and meanders with an order of magnitude less EKE than the deflection of the equatorwad flow, consistent with the seasonal variations in altimeter EKE (lower values in winter next to the coast) described by Kelly et al. [1998], Strub and James [2000] and quantified by Keister and Strub [2008].

[38] Interpretation of the relation between SSH and SST (Figure 4) fields is complicated by the presence of the cold Columbia River plume over the Washington shelf in winter and the coincidence of summer warming and upwelling. Thus lower SST values occur in the north over the shelf in winter, coincident with higher $\mathrm{SSH}$ values caused by downwelling, while lower SST values occur in the south over the shelf in summer, coincident with lower SSH values produced by the denser, upwelled water. Offshore, we find the expected pattern of relatively higher SST in late summer, with lower values in late winter (Figure 4).

[39] The Columbia River plume also complicates interpretation of the CHL fields, due to CDOM (and suspended sediments) over the Washington shelf. These contribute to the appearance (Figure 3) of high CHL in winter [Thomas and Weatherbee, 2006]. How much of this is real chlorophyll pigments remains to be determined, especially given the low values of chlorophyll pigment concentrations observed by in situ measurements over the Washington shelf in winter [Hermann et al., 1989]. The summer spatial pattern of $\mathrm{CHL}$ is probably more realistic, showing high values everywhere over the shelf, again revealing the influence of Heceta Bank and Cape Blanco in creating regions of expanded high concentrations inshore and offshore of the $200 \mathrm{~m}$ isobath (respectively), coincident with lower SST and SSH values. Maximum CHL values occur in August-September and reach more than $10 \mathrm{mg} \mathrm{m}^{-3}$ in the north. Similar CHL concentrations for the Washington shelf have been reported previously by Hermann et al. [1989], with blooms in excess of $20 \mathrm{mg} \mathrm{m}^{-3}$ on the Washington midshelf during the summer months.

[40] South of the Columbia River, CHL shows expected, consistent, inverse relationships with SST and SSH over the shelf: lower (higher) CHL values correspond to higher (lower) SST and SSH values in autumn-winter (springsummer), as lower SSH fields over colder, denser and nutrient-rich water upwelled in spring-summer change to higher SSH values over the warmer, less dense and nutrient poor offshore water that is transported next to the coast during winter downwelling. This inverse relationship between CHL and both SSH and SST is also reflected in the correlation coefficients on both intra-annual and interannual timescales.

[41] The point by point analysis of Legaard and Thomas [2006] provides some context for the wedge-like pattern of nonseasonal SST EOF 2 south of the Columbia River. This pattern is similar to the northern end of the region with the 
lowest magnitude of the annual harmonic over the entire California Current, and a greater percent of variance in the nonseasonal signals. The larger pattern shown by Legaard and Thomas continues to expand as one moves south along the California coast. The region with the highest annual amplitude is found offshore of Oregon and Washington, as also found here.

[42] The division of the coastal region between $41^{\circ}$ and $48.5^{\circ} \mathrm{N}$ into two dynamic regimes is similar to the division suggested by Huyer et al. [2005]. Using repeated hydrographic transects off $44.6^{\circ} \mathrm{N}$ and $41.9^{\circ} \mathrm{N}$, Huyer et al. [2005] describe Cape Blanco $\left(42.9^{\circ} \mathrm{N}\right)$ as dividing the fields from the two latitudes during summer upwelling. They find stronger upwelling winds south of the cape, similar to the fields in Figure 6 (May-October). Likewise, they describe an upwelling front and jet that is farther offshore south of the Cape, similar to the satellite SST and SSH fields for the same months presented in Figures 4 and 5 and consistent with climatological cross-shelf pigment patterns [Thomas and Strub, 2001]. The higher phytoplankton biomass they find in the south is represented in the satellite surface chlorophyll fields in May-June, but is not apparent in the July-August fields. This may reflect a difference between integrated biomass values from their in situ data, compared to the surface pigment fields from satellite data presented here. The satellite fields, however, make it clear that there is considerable alongshore variability in the width of the higher surface pigment fields, especially north of Cape Blanco. On a larger scale, Legaard and Thomas [2008] identify Cape Mendocino $\left(40^{\circ}-41^{\circ} \mathrm{N}\right)$ as the dividing point for regions in the entire California Current. Thus, on any scale examined, statistical analyses will divide the California Current into a few latitudinal subdomains. This is useful as a first-order characterization, but it will always oversimplify and ignore the large degree of alongshore and crossshore variability on smaller and larger scales.

[43] A final note concerning spatial variability draws attention to the region of narrow shelf and low variability between $44.5^{\circ}$ and $45.5^{\circ} \mathrm{N}$. Seasonal monthly mean fields of $\mathrm{CHL}, \mathrm{SST}$ and SSH are typically narrower in this region, as are the spatial fields for the nonseasonal EOF's. Likewise, monthly mean variance fields (not shown) for CHL, SST and SSH have distinct minima in this region. This is the region chosen for observation by the Coastal Upwelling Experiments (CUE) in the early 1970's, which resulted in fairly simple (and useful) first-order descriptions of 2-D (onshore-offshore) coastal upwelling [Huyer et al., 1978]. The location was chosen by examining the bottom topography and selecting the region with the simplest local variability, after initial surveys farther south, which proved difficult to interpret (A. Huyer, personal communication, 2007). We can see now that the location selected for CUE was the best choice for steady seasonal (summer) conditions and a lack of temporal variability. Choice of regions $100 \mathrm{~km}$ to the north or south would have resulted in a much more complicated initial picture of coastal upwelling.

4.2. Interannual Temporal Variability: El Niño Southern Oscillation, Other Distant Forcing, and Changes in Seasonal Timing

[44] On the shorter, intra-annual (monthly and to annual) timescales, we find the expected covariabilities between
TAU, CHL, SST and SSH. SST and CHL are negatively correlated, as described by Abbott and Zion [1985]. Equatorward alongshore wind stress is (moderately or marginally) correlated with higher CHL, lower SST and lower SSH. We concentrate below on the interannual timescales.

[45] Some of the interannual variability represents the midlatitude expression of the equatorial El Niño Southern Oscillation (ENSO) cycle [Huyer and Smith, 1985; Strub and James, 2002]. During the period studied here, there were strong and moderate El Niño events in 1997-1998 and 2002-2003, respectively. Our time series only marginally catch the end of the strong event. A strong La Niña occurred from late 1998 at least until early 2000 (or into 2001, depending on the variable examined). However, there are also factors other than the ENSO cycle that create interannual variability in the northern California Current.

[46] In Figure 11, we have overlaid some of the interannual time series, after removing the quadratic fit, which we will refer to as the trend. Unfortunately, the 11-point filter used to define the interannual timescale also eliminates the end of the 1997-1998 El Niño. This is seen by comparing the first EOF of SSH (Figure 11a, dark line) with the Multivariate ENSO Index (MEI; Figure 11d). The MEI drops from high values to 0 by mid-1998, when the $\mathrm{SSH}$ EOF 1 time series begins (the SSH EOF 1 time series shows the final fall to zero in mid-1998). However, the unfiltered SSH EOF 1 time series in Figure 8c clearly shows the drop in SSH during the end of the El Niño in the first half of 1998. The unfiltered SSH EOF 1 also shows a spike in early 2003, while the filtered SSH-1 in Figure 11 is high in autumn and winter, 2002-2003, during the moderate event. There do not appear to be strong signatures of the 20022003 event in the interannual time series for coastal SST, CHL or alongshore TAU. The cold SST values associated with the La Niña (1999-2001) are seen primarily in the time series for SST EOF 1 (Figures $8 \mathrm{~b}$ and 11b), which represents the more offshore SST signal (note that in Figures 8 and 10, trends are not removed; in Figure 11, they are).

[47] The MEI and NINO4 time series in Figure 11d have not been detrended and show a shift from cooler La Niña conditions in 1999 to warmer, more El Niño-like conditions during $2002+2005$. Comparisons to (un-detrended) time series for SST EOF 1 (Figure 8) and CHL EOF 2 (Figure 10) show trends that indicate warming of the offshore waters (SST EOF 1) and a shift from higher CHL in the north to higher CHL in the south (CHL EOF 2). However, correlations between the MEI and NINO4 indices and the interannual time series shown in Figure 11 are not enhanced by the trends, since the EOF time series have been detrended. The correlations between SST EOF 2 and the MEI and NINO4 are +0.32 and +0.39 , respectively, with highest correlations at zero lag. The correlations between SSH EOF 1 and the MEI and NINO4 are +0.35 and +0.37 with lags of 16 and 48 days, respectively. These are lower than the approximate 0.50 values needed for significance at the $95 \%$ level (for $15 \mathrm{df}$ ), although they are of the right sign for expected teleconnections between the equator and the Pacific Northwest.

[48] In the northern part of the California Current, there are interannual changes in conditions that are not due to ENSO changes. One is a well documented equatorward and onshore intrusion of colder and nutrient-rich subarctic water 

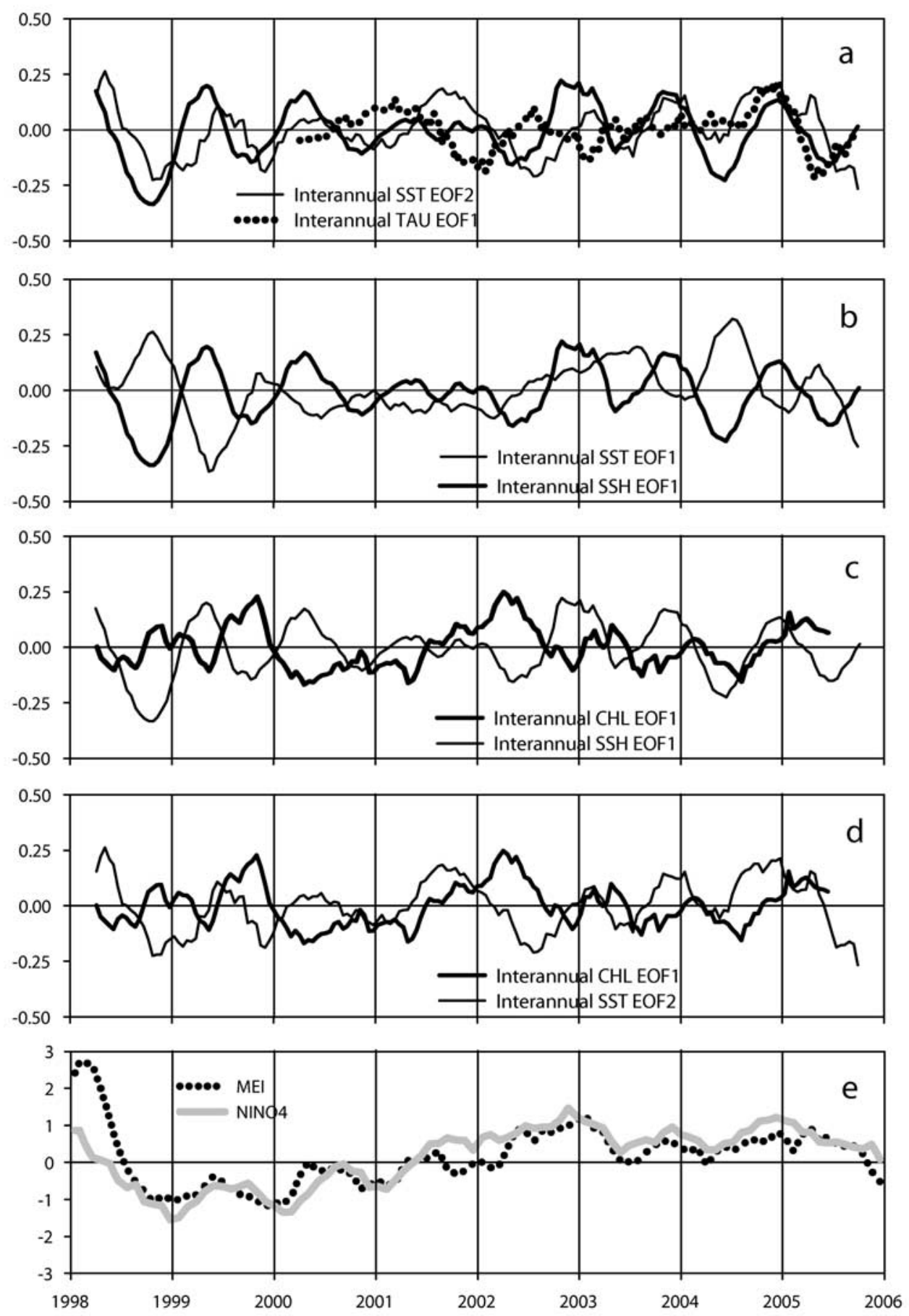

Figure 11. Overlays of the interannual (176-day running mean filter) time series for a number of the empirical orthogonal functions (EOFs). (a) Coastal sea surface height (SSH) EOF 1 (dark line), coastal sea surface temperature (SST) EOF 2 (light line), and alongshore wind stress (TAU) EOF 1 (dashed line); (b) coastal SSH EOF 1 (dark line) and offshore SST EOF 1 (light line); (c) coastal surface chlorophyll concentration (CHL) EOF 1 (dark line) and coastal SSH EOF 1 (light line); (d) coastal CHL EOF 1 (dark line) and coastal SST EOF 2 (light line); and (e) Multivariate ENSO Index (MEI) (dotted line) and NINO4 SST (solid line) El Niño indices.

within the pycnocline during 2002 [Freeland et al., 2003; Huyer, 2003; Wheeler et al., 2003; Thomas et al., 2003; Strub and James, 2003]. The interannual SST EOF 2 time series in Figure 11a and 11d shows the coldest summer SST values in mid-2002, excepting the late drop in SST in 2005.
These are due to strong summer spikes of negative SST values in mid-2002 in the unfiltered SST EOF 2 time series (Figure 10), also present in mid-2003. The interannual CHL EOF 1 time series in Figures 8 and 11 shows generally high values through most of 2002 that were produced by a 
number of unfiltered (Figure 8) positive peaks, with few negative values. A period of negative values for the time series of SSH EOF 1 in Figure 11a during the first half of 2002 has been interpreted to indicate stronger equatorward flow of the subarctic water [Strub and James, 2003], prior to lower SST and higher CHL values.

[49] Another period of unusual conditions off Oregon and Washington was the "warm anomaly" of spring 2005 [Hickey et al., 2006]. This event is attributed to weak and intermittent upwelling-favorable winds during spring and early summer off Oregon and northern California [Hickey et al., 2006; Barth et al., 2007]. The time series for the EOF of alongshore (equatorward) TAU (Figures 8d and Figure 11a) shows strong equatorward wind anomalies in autumnwinter 2004 (indicating weaker downwelling than usual), followed by strong poleward wind anomalies in springsummer 2005 (indicating weaker upwelling). The interannual time series for SST EOF 1 (offshore SST, Figure 8) and SST EOF 2 (coastal SST, Figure 10) both show warm anomalies extending from mid-2004 through mid-2005. The unfiltered coastal CHL values (CHL EOF 1, Figure 8) depict lower CHL values in fall 2004 and spring 2005. Two spikes of CHL in the unfiltered 2005 data follow brief periods of upwelling-favorable winds in late January-February and July 2005 [see also Henson and Thomas, 2007]. The time series are consistent with weak regional wind forcing in autumn-winter (weak downwelling), followed by late and weak upwelling during spring and the first half of summer, during this (approximately) one-year event.

[50] Perhaps the most notable feature of the interannual time series is the presence of quasi-annual cycles, even after removing the stationary harmonic seasonal cycles. This affects the calculations of the correlations between the interannual time series, producing correlation coefficients that cycle from high-to-low-to-high with a period of approximately one year. In our discussions of correlations between the interannual time series, we only used peaks in correlation with lags of zero to two 16-day time periods (one month lag, maximum). The primary purpose for Figure 11 is to show these time series overlaid, in order to allow a clear picture and evaluation of the relationships that create those correlations.

[51] Figure 11 shows two periods during which the quasiannual cycles are fairly well related, 1998-2000 and 20022005 , separated by a period when these relationships break down (late 2000 through 2001). Perhaps more importantly, the timing of the quasi-annual signals changes after 2001. For example, SSH EOF 1 and SST EOF 2 are positively correlated $(\mathrm{r}=+0.55)$, with peaks in the first half of the year prior to 2001 and peaks in the second half of the year after 2001. The cycles are not as clear for SST EOF 1 (Figure 11b) and CHL EOF 1 (Figure 11c), but they change from peaks occurring approximately late in the year in the early record to midyear at the end of the record. CHL EOF 1 also covaries out of phase with SSH EOF 1 (Figure 11c) and SST EOF 2 (Figure 11d). These represent changes in the timing of the seasonal cycles, which cannot be fit by the phase-locked harmonic seasonal cycles, producing the quasi-annual cycles in the interannual variability. Thus the correlations of the interannual time series do not represent only interannual variability with timescales of 2-7 years, but also include interannual variability in the timing and strength of the annual seasonal cycles.
[52] Although the quasi-annual nature of the signals makes interpretations of cyclical correlations problematic, the time series in Figure 11 demonstrate a high degree of covariability on scales shorter than quasi-annual. Examples include CHL EOF 1 and SST EOF 2 (Figure 11d; late 1998 and early 1999 and 2003) and CHL EOF 1 and SSH EOF 1 (Figure 11c; late 2002 to 2003). Even TAU EOF 1, although not significantly correlated over the entire record, shows covariability with SST EOF 2 (Figure 11a; 2000-2003). The wind stress time series is short and the relation appears to break down in winter 2004-2005, yet 2005 is the best documented case in which regional winds were clearly responsible for a delay in the upwelling season, the 2005 warm event [Hickey et al., 2006; Kosro et al., 2006; Barth et al., 2007]. Thus winds play an important role. Although attributing the change in seasonal cycle timing to a single cause with statistical certainty is not possible with the present, short data set, the time series in Figure 11 provide examples demonstrating that interannual changes in the circulation, SST and CHL can be driven by combinations of distant forcing from ENSO (1997-1998), effects of non-ENSO basin-scale circulation [2002] and regional winds (2005). Even using longer data sets (not satellite), with other years showing delayed or weak upwelling (similar to 2005), Schwing et al. [2006] find it difficult to attribute the cause to a single large-scale climate index. They conclude that the CCS upwelling system is too complex to describe with one such index.

[53] We note, however, that identifying changes in the timing of the seasonal cycles is an important result in itself. Variability in the timing of the circulation ( $\mathrm{SSH}$ ) and water properties (SST and CHL) have important ecological consequences, creating mismatches between different parts of the food chain (phytoplankton productivity, emergence of resting stages of zooplankton, migrations of juvenile fish, seabird breeding and feeding of young, etc.), as discussed by Cushing [1990], Barth et al. [2007], Sydeman et al. [2006] and Brodeur et al. [2006]. These types of changes are also hypothesized as possible consequences of climate change [Snyder et al., 2003]. Further analyses of present data sets which examine the mechanisms in detail may help to improve our understanding of how climate change may affect ecosystems in the northern California Current, along with our ability to model those effects.

\section{Conclusions}

[54] Using 8 years of satellite-derived CHL, SSH, SST data and 6 years of TAU data over the northern California Current, we draw the following conclusions:

[55] 1. The mean fields and seasonal cycles of circulation (SSH) and water properties (SSH, SST) are mostly as expected, with an emphasis on the importance of topographic forcing by the Heceta Bank and Cape Blanco during both winter and summer (Figures 3-6).

[56] 2. The latitude band where the mean wind stress switches from upwelling to downwelling-favorable is between $44^{\circ}$ and $46^{\circ} \mathrm{N}$ (Figure 2). Mean alongshore wind stress is approximately upwelling-neutral in this band, owing to the cancellation of seasonally alternating winds of equal strength (Figure 6).

[57] 3. The region from northern California to the Canadian border separates into two general areas, with a dividing 
region around $44^{\circ}-46^{\circ} \mathrm{N}$. This may be due to wind forcing, topography or the presence of the Columbia River Plume (Figures 7 and 9). However, detailed fields show a great deal of alongshore and cross-shelf variability, including a region of low variability over the narrow shelf between $44.5^{\circ}$ and $45.5^{\circ} \mathrm{N}$ (the classic 2-D upwelling system).

[58] 4. In general, variability is dominated by nonseasonal variability $(60-75 \%)$ compared to seasonal variability (Table 1). The exception is SST, but that is controlled by offshore seasonal warming, rather than dynamical signals.

[59] 5. Nonseasonal variability in the coastal fields is dominated by intra-annual variability $(75-90 \%)$, compared to interannual variability (Table 3; Figures 8 and 10). The exception is coastal SSH (EOF1), where interannual variability accounts for $60 \%$ of the nonseasonal variability.

[60] 6. On intra-annual scales, the correlations are as expected, with highest correlations between coastal CHL and SST, weaker correlations between alongshore TAU and the other variables.

[61] 7. On interannual timescales, the period of study includes moderate ENSO variability, but is not dominated by it. There are several non-ENSO interannual events, forced by changes in large-scale circulation (the 2002 subarctic intrusion) and by local-regional changes in wind forcing (the 2005 warm anomaly).

[62] 8. Statistically, on interannual timescales, alongshore TAU is not correlated significantly with the other variables. However, the TAU record is short and includes the apparent influence of the alongshore TAU on the 2005 warm anomaly, as well as covariability with interannual fluctuations in SST during most of the record. All of the other variables are correlated at about $|\mathrm{r}|=0.5-0.6$.

[63] 9. However, the correlations between coastal SSH, SST and CHL on interannual timescales are difficult to evaluate owing to a residual quasi-annual signal in each record (Figure 11), caused by a change in the timing of the seasonal cycles. Visually, the time series appear correlated on several timescales, not just quasi-annual, providing evidence that the covariability is real, although the forcing is still uncertain.

[64] 10. The changes in timing of the seasonal cycles need further study.

[65] Acknowledgments. Support for R. V. and P. T. S. was provided by the U.S. GLOBEC program in the northeast Pacific (National Science Foundation (NSF) grant OCE-0000900). Additional support for P. T. S. and R. L. was provided by the U.S. GLOBEC program (NOAA grant NA03NES00001), with partial support for P. T. S. also provided by NASA Jet Propulsion Laboratory (JPL) (grant JPL-1206714-OSTM). Participation by E. B. is part of Consejo Nacional de Ciencia y Tecnologia (CONACYT) project SEP-2003-C02-42941/A-1. A. C. T. was supported by NSF grants OCE-0535386 and OCE-0531289. Support for T. C. came from the NSF (U.S. GLOBEC program grant OCE-0001035). Altimeter data were provided by JPL (http://podaac.jpl.nasa.gov/ost/). Scatterometer data were provided by Mike Freilich at Oregon State University and the JPL archive (http://winds.jpl.nasa.gov/). Sea surface temperature and Sea Viewing Wide Field of View Sensor (SeaWiFS) data were provided by the U.S. GLOBEC program North East Pacific (NEP) project (http://coho.coas.oregonstate. edu/), the West Coast CoastWatch node (http://coastwatch.pfel.noaa.gov/) and the NASA Goddard Space Flight Center archive (http://oceancolor.gsfc. nasa.gov/). The manuscript benefited from the comments of two anonymous reviewers. This is contribution 561 of the U.S. GLOBEC program, jointly funded NSF and NOAA.

\section{References}

Abbott, M. R., and B. Barksdale (1991), Phytoplankton pigment patterns and wind forcing off central California, J. Geophys. Res., 96, 14,64914,667 .
Abbott, M. R., and P. M. Zion (1985), Satellite observation of phytoplankton variability during an upwelling event, Cont. Shelf Res., 4, 661-680.

Bakun, A., and C. S. Nelson (1991), The seasonal cycle of wind stress curl in subtropical eastern boundary current regions, J. Phys. Oceanogr., 21, $1815-1834$

Barth, J. A., S. D. Pierce, and R. L. Smith (2000), A separating upwelling coastal jet at Cape Blanco, Oregon, and its connection to the California Current System, Deep Sea Res., Part II, 47, 783-810.

Barth, J. A., S. D. Pierce, and R. J. Cowles (2005), Mesoscale structure and its seasonal evolution in the northern California Current System, Deep Sea Res., Part II, 52, 5-28.

Barth, J. A., B. A. Menge, J. Lubchenco, F. Chan, J. M. Bane, A. R. Kirincich, M. A. McManus, J. Nielsen, S. D. Pierce, and L. Washburn (2007), Delayed upwelling alters nearshore coastal ocean ecosystems in the northern California current, Proc. Natl. Acad. Sci. U. S. A., 104, 3719-3724.

Brodeur, R. D., S. Ralston, R. L. Emmett, M. Trudel, T. D. Auth, and A. J. Phillips (2006), Anomalous pelagic nekton abundance, distribution, and apparent recruitment in the northern California Current in 2004 and 2005, Geophys. Res. Lett., 33, L22S08, doi:10.1029/2006GL026614.

Castelao, R. M., J. A. Barth, and T. P. Mavor (2005), Flow-topography interactions in the northern California Current System observed from geostationary satellite data, Geophys. Res. Lett., 32, L24612, doi:10.1029/ 2005GL024401.

Chavez, F. P., J. T. Pennington, C. G. Castro, J. P. Ryan, R. P. Michisaki, B. Schlining, P. Walz, K. R. Buck, A. McFayden, and C. A. Collins (2002), Biological and chemical consequences of the 1997-1998 El Niño in central California waters, Prog. Oceanogr., 54, 205-232.

Chavez, F. P., J. Ryan, S. E. Lluch-Cota, and M. Niguen (2003), From anchovies to sardine and back: Multidecadal changes in the Pacific Ocean, Science, 299, 217-221.

Chelton, D. B. (1982), Large-scale response of the California Current to forcing by wind stress curl, Rep. 23, pp. 130-148, Calif. Coop. Oceanic Fish. Invest., Univ. of Calif., San Diego, La Jolla, Calif.

Cushing, D. H. (1990), Plankton production and year-class strength in fish populations: An update on the match/mismatch hypothesis, Adv. Mar. Biol., 26, 249-293.

Emery, W. J., and R. E. Thomson (1998), Data and their analysis methods in physical oceanography, 1st and 2nd eds., 634 pp., Pergamon Press, Amsterdam.

Enriquez, A. G., and C. A. Friehe (1995), Effects of wind stress and wind stress curl variability on coastal upwelling, J. Phys. Oceanogr., 25, 1651-1671.

Freeland, H. J., G. Gatien, A. Huyer, and R. L. Smith (2003), Cold halocline in the northern California Current: An invasion of subarctic water, Geophys. Res. Lett., 30(3), 1141, doi:10.1029/2002GL016663.

Haidvogel, D. B., J. Wilkin, and R. Young (1991), A semi-spectral primitive equation ocean circulation model using vertical sigma and horizontal orthogonal curvilinear coordinates, J. Comp. Phys., 94, 151-185.

Haidvogel, D. B., A. Beckmann, and K. S. Hedstrom (2001), Dynamical simulations of filament formation and evolution in the Coastal Transition Zone, J. Geophys. Res., 96, 15,017-15,040.

Henson, S. A., and A. C. Thomas (2007), Interannual variability in timing of bloom initiation in the California Current System, J. Geophys. Res., 112, C08007, doi:10.1029/2006JC003960.

Hermann, A. J., B. M. Hickey, M. R. Landry, and D. F. Winter (1989), Coastal upwelling dynamics, in Coastal Oceanography of Washington and Oregon, edited by M. R. Landry and B. M. Hickey, pp. 211-254, Elsevier, New York.

Hickey, B. M. (1979), The California Current System-Hypotheses and facts, Prog. Oceanogr., 8, 191-279.

Hickey, B. M. (1989), Pattern and processes of circulation over the continental shelf of Washington, in Coastal Oceanography of Washington and Oregon, edited by M. R. Landry and B. M. Hickey, pp. 41-115, Elsevier, New York.

Hickey, B. M. (1998), Coastal oceanography of western North America from the tip of Baja California to Vancouver Island, in The Sea, vol 11, edited by A. R. Robinson and K. H. Brink, pp. 345-393, Harvard Univ. Press, Cambridge, Mass.

Hickey, B., A. MacFadyen, W. Cochlan, R. Kudela, K. Bruland, and C. Trick (2006), Evolution of chemical, biological, and physical water properties in the northern California Current in 2005: Remote or local wind forcing?, Geophys. Res. Lett., 33, L22S02, doi:10.1029/2006GL026782.

Hill, A. E., B. M. Hickey, F. A. Shillington, P. T. Strub, K. H. Brink, E. D. Barton, and A. C. Thomas (1998), Eastern ocean boundaries, in The Sea, vol. 11, edited by A. R. Robinson and K. H. Brink, pp. 29-67, Harvard Univ. Press, Cambridge, Mass.

Huyer, A. (1983), Coastal upwelling in the California Current System, Prog. Oceanogr., 12, 259-284.

Huyer, A. (2003), Preface to special section on enhanced Subarctic influence in the California Current, 2002, Geophys. Res. Lett., 30(15), 8019, doi:10.1029/2003GL017724. 
Huyer, A., and R. L. Smith (1985), The signature of El Niño of Oregon, 1982-1983, J. Geophys. Res., 90, 7133-7142.

Huyer, A., R. D. Pillsbury, and R. M. Smith (1975), Seasonal variation of alongshore velocity field over the continental shelf off Oregon, Limnol. Oceanogr., 20, 90-95.

Huyer, A., R. L. Smith, and E. J. C. Sobey (1978), Seasonal differences in low-frequency current fluctuations over the Oregon continental shelf, J. Geophys. Res., 83, 5077-5089.

Huyer, A., E. J. Sobey, and R. L. Smith (1979), The spring transition in currents over the Oregon continental shelf, J. Geophys. Res., 84, 6995-7011.

Huyer, A., P. M. Kosro, J. Fleischbein, S. R. Ramp, T. Stanton, L. Washburn, F. P. Chavez, T. J. Cowles, S. D. Pierce, and R. L. Smith (1991), Currents and water masses of the Coastal Transition Zone off northern California, June to August 1988, J. Geophys. Res., 96, 14,809-14,832.

Huyer, A., J. H. Fleischbein, J. Keister, P. M. Kosro, N. Perlin, R. L. Smith, and P. A. Wheeler (2005), Two coastal upwelling domains in the northern California Current system, J. Mar. Res., 63, 901-929.

Ikeda, M., and W. J. Emery (1984), Satellite observations in modeling of meanders in the California Current System of Oregon and northern California, J. Phys. Oceanogr., 14, 1434-1450.

Kahru, M., and G. Mitchell (2000), Influence of 1997-1998 El Niño on the surface chlorophyll in the California Current, Geophys. Res. Lett., 27, 2937-2940.

Keister, J. E., and P. T. Strub (2008), Spatial and interannual variability in mesoscale circulation in the northern California Current System, J. Geophys. Res., doi:10.1029/2007JC004256, in press.

Kelly, K. A., R. C. Beardsley, R. Limeburner, K. H. Brink, J. D. Paduan, and T. K. Chereskin (1998), Variability of the near-surface eddy kinetic energy in the California Current based on altimeter, drifter, and moored current data, J. Geophys. Res., 103, 13,067-13,083

Kosro, P. M., et al. (1991), The structure of the transition zone between coastal waters and the open ocean off northern California, winter and spring 1987, J. Geophys. Res., 96, 14,707-14,730.

Kosro, P. M., W. T. Peterson, B. M. Hickey, R. K. Shearman, and S. D. Pierce (2006), Physical versus biological spring transition: 2005, Geophys. Res. Lett., 33, L22S03, doi:10.1029/2006GL027072.

Legaard, K. R., and A. C. Thomas (2006), Spatial patterns in seasonal and interannual variability of chlorophyll and sea surface temperature in the California Current, J. Geophys. Res., 111, C06032, doi:10.1029/ 2005JC003282.

Legaard, K. R., and A. C. Thomas (2008), Spatial patterns of intraseasonal variability of chlorophyll and sea surface temperature in the California Current, J. Geophys. Res., 112, C09006, doi:10.1029/2007JC004097.

Levitus, S., T. P. Boyer, M. E. Conkright, T. O’Brien, J. Antonov, C. Stephens, L. Stathopolos, D. Johnson, and R. Gelfeld (1998), World Ocean Database 998, vol. 1, Introduction, NOAA Atlas NESDIS 18, Natl. Oceanic and Atmos. Admin., Silver Spring, Md.

Lynn, R. J., and J. J. Simpson (1987), The California Current System: The seasonal variability of physical characteristics, J. Geophys. Res., 92, $12,947-12,966$

Mackas, D. L. (2006), Interdisciplinary oceanography of the western North American continental margin: Vancouver Island to the tip of Baja California, in The Sea, vol. 14, edited by A. R. Robinson and K. H. Brink, pp. 441-502, Harvard Univ. Press, Cambridge, Mass.

Mackas, D. L., P. T. Strub, A. C. Thomas, and V. Montecino (2006), Eastern ocean boundaries, in The Sea, vol. 14, edited by A. R. Robinson and K. H. Brink, pp. 21-60, Harvard Univ. Press, Cambridge, Mass.

Mantua, N. J., S. R. Hare, Y. Zhang, J. M. Wallace, and R. C. Francis (1997), A Pacific decadal climate oscillation with impacts on salmon, Bull. Am. Meteorol. Soc., 78, 1069-1079.

McGowan, J. A., D. B. Chelton, and A. Conversi (1996), Plankton pattern, climate and change in the California Current, Rep. 37, pp. 45-68, Calif Coop. Ocean. Fish. Invest., Univ. of Calif., San Diego, Calif.

McGowan, J. A., D. R. Cayan, and L. M. Dorman (1998), Climate-ocean variability and ecosystem response in the northeast Pacific, Science, 281 , $210-217$

Munchow, A. (2000), Wind stress curl forcing of the coastal ocean near Point Conception, California, J. Phys. Oceanogr., 30, 1265-1280.

O’Reilly, J. E., S. Maritorena, B. G. Mitchell, D. A. Siegel, K. L. Carder, S. A. Garver, M. Kahru, and C. McClain (1998), Ocean color chlorophyll algorithms for SeaWiFS, J. Geophys. Res., 103, 24,937-24,953.

Pauly, D., and V. Christensen (1995), Primary production required to sustain global fisheries, Nature, 374, 255-257.

Pelaez, J., and J. A. McGowan (1986), Phytoplankton pigment patterns in the California Current as determined by satellite, Limnol. Oceanogr., 31, 927-950.

Preisendorfer, R. W. (1988), Principal Component Analysis in Meteorology and Oceanography, Elsevier, New York.

Schwing, F. B., N. A. Bond, S. J. Bograd, T. Mitchell, M. A. Alexander, and N. Mantua (2006), Delayed coastal upwelling along the U.S. West
Coast in 2005: A historical perspective, Geophys. Res. Lett., 33, L22S01, doi:10.1029/2006GL026911.

Smith, R. C., X. Zhang, and J. Mickelsen (1988), Variability of pigment biomass in the California Current System as determined by satellite imagery, 1. Spatial variability, J. Geophys. Res., 93, 10,863-10,882.

Smith, R. L., A. Huyer, and J. Fleischbein (2001), The coastal ocean off Oregon from 1961 to 2000: Is there evidence of climate change or only of Los Niños?, Prog. Oceanogr., 49, 63-93.

Snyder, M. A., L. C. Sloan, N. S. Diffenbaugh, and J. L. Bell (2003), Future climate change and upwelling in the California Current, Geophys. Res. Lett., 30(15), 1823, doi:10.1029/2003GL017647.

Strub, P. T., and C. James (1995), The large-scale summer circulation of the California Current, Geophys. Res. Lett., 22, 207-210.

Strub, P. T., and C. James (2000), Altimeter-derived variability of surface velocities in the California Current System: 2. Seasonal circulation and eddy statistics, Deep Sea Res., Part II, 47, 831-870.

Strub, P. T., and C. James (2002), The 1997-1998 Oceanic El Niño signal along the southeast and northeast Pacific boundaries-An altimetry view, Prog. Oceanogr., 54, 439-458.

Strub, P. T., and C. James (2003), Altimeter estimates of anomalous transports into the northern California Current during 2000-2002, Geophys. Res. Lett., 30(15), 8025, doi:10.1029/2003GL017513.

Strub, P. T., J. S. Allen, A. Huyer, R. L. Smith, and R. C. Beardsley (1987a), Seasonal cycles of currents, temperatures, winds, and sea level over the northeast pacific continental shelf: $35^{\circ} \mathrm{N}$ to $48^{\circ} \mathrm{N}, J$. Geophys. Res., 92, 1507-1526.

Strub, P. T., J. S. Allen, A. Huyer, and R. L. Smith (1987b), Large-scale structure of the spring transition in the coastal ocean off western North America, J. Geophys. Res., 92, 1527-1544.

Strub, P. T., C. James, A. Thomas, and M. Abbott (1990), Seasonal and nonseasonal variability of satellite-derived surface pigments concentration in the California Current, J. Geophys. Res., 95, 11,501-11,530.

Strub, P. T., P. M. Kosro, A. Huyer, and CTZ Collaborators (1991a), The nature of the cold filaments in the California Current system, J. Geophys. Res., 96, 14,743-14,768.

Strub, P. T., P. M. Kosro, and A. Huyer (1991b), The nature of cold filaments in the California Current Systems, J. Geophys. Res., 96, 14,743-14,768.

Sydeman, W. J., R. W. Bradley, P. Warzybok, C. L. Abraham, J. Jahncke, K. D. Hyrenbach, V. Kousky, J. M. Hipfner, and M. D. Ohman (2006), Planktivorous auklet Ptychoramphus aleuticus responses to ocean climate, 2005: Unusual atmospheric blocking?, Geophys. Res. Lett., 33, L22S09, doi:10.1029/2006GL026736.

Thomas, A. C., and P. T. Strub (1989), Interannual variability in phytoplankton pigment distribution during the spring transition along the west coast of North America, J. Geophys. Res., 94, 18,095-18,117.

Thomas, A. C., and P. T. Strub (1990), Seasonal and interannual variability of pigment concentrations across a California Current frontal zone, J. Geophys. Res., 95, 13,023-13,042.

Thomas, A. C., and P. T. Strub (2001), Cross-shelf phytoplankton pigment variability in the California Current, Cont. Shelf Res., 21, $1157-1190$

Thomas, A. C., and R. A. Weatherbee (2006), Satellite-measured temporal variability of the Columbia River plume, Remote Sens. Environ., 100, $167-178$.

Thomas, A. C., F. Huang, P. T. Strub, and C. James (1994), Comparison of the seasonal and interannual variability of phytoplankton pigment concentrations in the Peru and California Current Systems, J. Geophys. Res., 99, 7355-7370

Thomas, A. C., M.-E. Carr, and P. T. Strub (2001), Chlorophyll variability in eastern boundary currents, Geophys. Res. Lett., 28, 3421-3424.

Thomas, A. C., P. T. Strub, and P. Brickley (2003), Anomalous satellitemeasured chlorophyll concentrations in the northern California Current in 2001-2002, Geophys. Res. Lett., 30(15), 8022, doi:10.1029/ 2003GL017409.

Wheeler, P. A., A. Huyer, and J. Fleischbein (2003), Cold halocline, increased nutrients and higher chlorophyll off Oregon in 2002, Geophys. Res. Lett., 30(15), 8021, doi:10.1029/2003GL017395.

E. Beier and C. Cabrera, Centro de Investigación Científica y Educación Superior de Ensenada, Km. 107 Carretera Tijuana-Ensenada, Código Postal 22860, Apdo. Postal 360, Ensenada, B.C. México.

T. Cowles, C. James, R. Letelier, P. T. Strub, and R. M. Venegas, College of Oceanic and Atmospheric Sciences, Oregon State University, 104 COAS Administration Building, Corvallis, OR 97331-5503, USA. (rvenegas@ coas.oregonstate.edu)

L. Soto-Mardones, Departamento de Física, Facultad de Ciencias, Universidad del Bio-Bio, Casilla 5-C, Avenida Collao 1202, Concepcion, Chile.

A. C. Thomas, School of Marine Sciences, University of Maine, 5706 Aubert Hall, Room 306, Orono, ME 04469-5706, USA 